2003

\title{
The Serpent Beguiled Me: A History of the Entrapment Defense
}

Rebecca Roiphe

New York Law School, rebecca.roiphe@nyls.edu

Follow this and additional works at: https://digitalcommons.nyls.edu/fac_articles_chapters

Part of the Criminal Law Commons, and the Legal History Commons

\section{Recommended Citation}

Seton Hall Law Review, Vol. 33, Issue 2 (2003), pp. 257-302

This Article is brought to you for free and open access by the Faculty Scholarship at DigitalCommons@NYLS. It has been accepted for inclusion in Articles \& Chapters by an authorized administrator of DigitalCommons@NYLS. 


\title{
The SerPent Beguiled Me: A History Of THE ENTRAPMENT DEFENSE
}

\author{
Rebecca Roiphe*
}

\section{INTRODUCTION}

In 1864, a New York trial court confronted a fairly run-of-the-mill entrapment defense.' The judge, like most judges at the time, rejected the defense, admonishing that the great Lawgiver overruled such tactics back when Eve complained, "the serpent beguiled me,

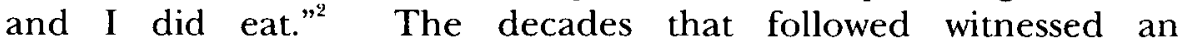
unprecedented retreat from this lofty precedent. State and federal courts throughout the union began to recognize and elaborate on the entrapment defense around the turn of the century. ${ }^{3}$ In 1932, the Supreme Court followed in kind by holding the defense implicit in all federal criminal statutes. ${ }^{4}$ Ever since, entrapment has occupied a rather small and uncontroversial corner of criminal law. Recently, however, courts and scholars have struggled to define entrapment in the context of increasingly intrusive law enforcement techniques. ${ }^{5}$

Analyzed in various ways, the entrapment defense excuses a defendant when the actions of government officials produced the crime of which he stands charged. Since its inception, most courts have employed a subjective test, asking whether the individual

* Assistant District Attorney, New York County District Attorney's Office. Golieb Fellow 2001-02, New York University; Ph.D 2002, University of Chicago; J.D. 2000, Harvard Law School; B.A. 1993, Columbia University. Countless friends and colleagues have given me useful advice and challenging comments. Special thanks to Larry Kramer, Daniel Meltzer, William E. Nelson, Morton Horwitz, Barbara Black, Michael Herz, Dana Brakman, Amy Dru Stanley, George Chauncey, and Jan Goldstein. I would also like to thank participants of the Legal History Colloquium at New York University for their insights.

1 Bd. of Comm'rs of Excise v. Backus, 29 How. Pr. 33 (N.Y. Sup. Ct. 1864).

2 Id. at 33.

3 See generally infra PART II (discussing the history of the entrapment defense).

4 Sorrells v. United States, 287 U.S. 435 (1932).

5 The nature and scope of the entrapment defense has become especially controversial in the context of federal efforts to capture criminals using the Internet. See Neal Kumar Katyal, Criminal Law in Cyberspace, 149 U. PA. L. Rev. 1003, 1008 (2001). 
defendant was predisposed to commit the crime before encouraged to do so by some state actor. ${ }^{6}$ A minority of courts and many commentators, however, espouse a test that inquires whether law enforcement officials acted in an objectively reasonable way. Entrapment was born in an era when most areas of the law were tilting away from subjective tests toward more objective tests. ${ }^{8}$ This article seeks to answer (1) why entrapment emerged when it did and (2) why courts stubbornly cling to an outmoded subjective entrapment analysis.

The answer to the first of these questions is, on one level, quite simple. After the Civil War, state governments grew and police forces grew with them. As the federal government expanded, so too did its arm of law enforcement. The people needed protection from this law enforcement leviathan and sought this protection in the courts. By the end of the century, the machinery of the state had transformed so radically that the law could no longer protect individuals by securing a boundary around their person and their property. Serving as neutral arbiter between one individual and the next proved not only insufficient, but also impossible. Notions of voluntary contractual relations, even stretched to their extreme, could not accommodate the modern state with its many tentacles reaching into realms of privacy that people never thought could be threatened. ${ }^{9} \quad$ Sting operations conducted by state and federal detectives offered a fairly concrete example of how government had outgrown its neutral status. Thus, the state seemed both impersonal-in its growingly distant, bureaucratic, and centralized form-and, ironically, visible-in officers' presence in the average citizen's daily life. Entrapment emerged in response to the conflict between these two visions of the state as one of many turn-of-thecentury legal developments that subtly redrew the boundary between the individual and the government.

This brings us to the answer to the second question. As the law of contract, tort, and property all espoused an objective test, the space for free will and autonomy in the law diminished, leaving a

${ }^{6}$ See generally infra PART III.

Id.

8 See Morton Horwttz, The Transformation of American Law, 1870-1960: THE CRISIS OF LEGAL ORTHODOXY 35-40 (1992).

${ }^{9}$ See id.; see also Grant Gilmore, THE Ages of AMERICAN LAW (1977); James Willard HuRST, LAW aNd THE CONDITIONS OF FREEDOM IN THE NinETEENTH-CENTURY UNITED STATES (1956); WILlIAM E. NELSON, AMERICANIZATION OF THE COMMON LAW: THE IMPACT OF Legal CHANGE ON MASSACHuSETTS SOCIETY, 1760-1830 (1975); William E. Nelson, The RoOts Of AMERICAN BuREAuCRACY, 1830-1900 (1982). 
theoretical vacuum in its wake. As Morton Horwitz explained, by the time the progressive legal thinkers launched their attack on natural rights in the 1920s and 30s, the idea that the law could actually uncover some real subjective intent and preserve a sacred area of free will was already largely discredited. ${ }^{10}$ The vast and complicated nature of modern economic interactions had rendered that ideal mythical, at best." So, Oliver Wendell Holmes's reasonable man took the place of each individual and policy determined how that reasonable man should and would act in any given instance. ${ }^{12}$ Legal historians argue that this set the stage for the law's turn to the social sciences. ${ }^{19}$ Courts, however, never collapsed into mere brokers for different social scientific theories, and the notion that the law can, and should, seek to define subjective intent, freedom, and autonomy did not disappear. Rather, it migrated to different areas and took different forms. By uncovering those forms, we begin to catch a glimpse of how the law redefined freedom and individuality in reaction to the new constellation of economic, social, and political forces. $^{14}$

Thus, entrapment grew as a response to the increasingly pervasive and invasive forms of law enforcement, but it was not an inevitable reaction to the sudden expansion in the nature and scope of state and federal police power. Entrapment emerged as a piece of a puzzle: an innovative way to police the boundaries between government and the individual in the newly drawn precincts of the modern state. I have divided my discussion of the history of entrapment law to illustrate this thesis. Part I of this article briefly reviews the social and political context of post-Civil War America and elaborates on the changes in law enforcement at the time. Part II discusses the history of both the state and federal defense of

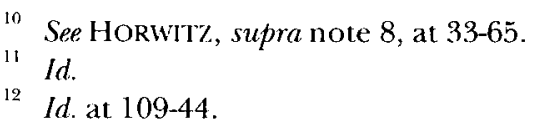
Naturalism and the Problem of Value 13-115 (1973). In general, the turn to the social sciences could not solve the problem of determinism in the law. Most of the social sciences, after all, provided natural or psychological explanations for all human behavior. See H. STUART Hughes, Consciousness AND Societr: The REORIENTATION OF EuROPEAN SOCIAI. THOUGHT, 1890-1930, at 4-5 (1977). The law was left to concede or to find a new place for freedom within its doctrine.

14 In researching entrapment, I have relied on Michel Foucault's notion of "archaeology." Thus, the particular history of entrapment seems to me evidence of a significant mutation in the law. By analyzing the shift in this system of thought, we begin to understand the nature of individuality in the twentieth century, something that, to the modern eye, might seem inevitable, unquestionable, or necessary. See MiChel. Foucault, ThE ARCHAEOLOGY OF KNOWLEDGe (1972). 
entrapment. Part III analyzes some of the implications of this history, gives an overview of the current debate over how the defense ought to function, and places it in context of the history of entrapment law. Finally, without falling too easily into the trap that history, custom, and past practice should dictate policy, I will argue that given the history of entrapment, a modified subjective test provides the appropriate analysis. ${ }^{15}$ In addition, the history of entrapment illustrates how the defense fits into criminal law and counsels against extending it to cases where private parties rather than government officials entrap an individual.

\section{HISTORY OF LAW ENFORCEMENT}

Organized state police forces are a relatively modern innovation. In the colonial period, citizens bore a collective responsibility for law enforcement and every adult male shared a duty to serve as constable or hire someone to take his turn. ${ }^{16}$ As individuals grew increasingly wary of such periodic police duties, many towns began to elect constables who would hire a number of watchmen, and the powers of the police increased gradually. ${ }^{17}$ These constables had broad administrative responsibilities beyond law enforcement. ${ }^{18}$

Prior to the mid-nineteenth century, the police remained loosely organized and largely ineffectual. ${ }^{19}$ Most towns employed one chief and a dozen or so patrolmen. ${ }^{20}$ The towns paid their chief fees for certain tasks rather than a salary and the chief, in turn, paid the patrolmen. ${ }^{21}$ In most cases, victims bore the cost of prosecution, and

${ }^{15}$ For a pathbreaking review of the role that history has, and should, play in legal thought, see Martin S. Flaherty, History "Lite" in Modern American Constitutionalism, 95 COLUM. L. REV. 523 (1995).

${ }^{16}$ David R. Johnson, American Law Enforcement: A History 5-7 (1981). The active involvement of citizens in policing dated back to England in the tenth century when each citizen was responsible for neighbors who had been victimized. This informal community model went through various permutations until Oliver Cromwell modified the "constabulary" into a mounted cavalry to serve the role of police. See Kenneth J. PeAK, Policing America 5-6 (1997). In 1663, King Charles II replaced this force with a night watch and constable system composed primarily of old men, commonly called the "Old Charlies." GEORGE ASTOR, THE NEW YORK COPS 10 (1971). The dominant law enforcement persona in the rural south was the sheriff rather than the constable. See Frank Richard PRASSEL, THE WeStern PEACE Officer: A LEGACY OF LAW AND ORDER 94 (1972).

17 JOHNSON, supra note 16 , at 7 .

Id. at 3.

19 Eric H. MonkKonen, Police In Urban AmEriCA, 1860-1920, at 42-48 (1981) [hereinafter MONKKONEn, POLICE In URBAN AMERICA].

${ }^{20}$ Id. at $46-49$.

${ }^{21}$ Id. at 61 . 
as a result, police tended to focus on crimes against property, leaving many more violent personal crimes unsolved. ${ }^{22}$

Law enforcement in the southern colonies was similarly haphazard, consisting, in most cases, of a single sheriff who harbored a vast number of responsibilities on top of policing. ${ }^{23}$ Towns in the south, however, faced the additional problein of slave insurrections. Beginning in the early eighteenth century, southern citizens supplemented the nascent police department by serving on "slave patrols" designed to retrieve runaway slaves and prevent slave revolts. ${ }^{24}$ Territorial expansion and tensions produced by slavery stretched the limits of community policing. Throughout the rural south and the west, wherever sheriffs and slave patrols failed to preserve the peace, bands of vigilantes filled the vacuum. ${ }^{25}$

The turn of the eighteenth century witnessed unprecedented urban growth. Between 1790 and 1830, due in part to immigration from central and northern Europe, as well as mass industrialization and migration from rural America, cities almost quadrupled in size. ${ }^{26}$ In the decades after 1830 , urban centers experienced a population boom that would not subside for close to a century. ${ }^{27}$ Faced with increased crime and social tension that accompanied such sudden growth and diversity, the larger American cities took their cue from across the Atlantic and began to establish more organized hierarchical police forces designed primarily to prevent crime by

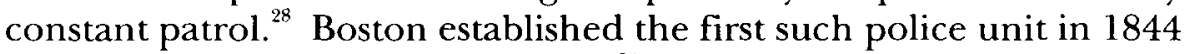
and New York followed suit in $18544^{29}$ In the following decades, most American cities created similar organizations, but, unlike their British

22 Id. at 35 .

23 Brian Vila \& Cynthia Morris, The Role of Police in American Society: A Documentary History 14-15 (1999).

${ }^{24}$ Id. at 14-17. Shortly after its successful struggle for independence, Texas established its own police force, called the Texas Rangers, to protect the frontier from Mexicans and the Indians. The Rangers persisted after Texas joined the Union in 1845 but they were absorbed into the Confederate army during the war and ultimately displaced by the state police instituted during Reconstruction. When the Democrats took power in 1874 , they reestablished the Rangers. PRASSEL, supra note 16 , at $151-54$.

25 Robert M. REgoli \& JOHN D. HewtTt, CRIMINAL JUSTICE 221 (1996); see also PRASSEL, supra note 16, at 76-78.

${ }^{26}$ VILA \& MORRIS, supra note 23, at 25.

${ }^{27}$ ERIC H. MONKKONEN, AMERICA Becomes URBAN: THE DEVElopment OF U.S. CITIES \& TOWNS, 1780-1980, at 70 (1988) [hereinafter MONKKONEN, AMERICA BECOMES URBAN].

28 Samuel Walker, a Critical. History of Police Reform: The Emergence of ProfESSIONALISM 53-61 (1977).

29 JOHNSON, supra note 16 , at 26-27. 
counterpart, the police throughout America remained under municipal control throughout the century. ${ }^{30}$ The decentralized local nature of American policing persisted, in part, out of adherence to an important theoretical ideal tying the people to the execution of their laws. The European state and national police forces-far removed from ordinary citizens-were perceived as uniquely undemocratic, quasi-military forces. ${ }^{31}$ Alexis de Tocqueville commented on the decentralized structure of American law enforcement, observing that it was nonetheless effective because individuals felt that reporting crimes and assisting in law enforcement was an integral part of their responsibility as citizens of a democratic state. $^{32}$ What is important is not the accuracy of Tocqueville's somewhat romantic rendition of American law enforcement, but rather the theoretical appeal of local, decentralized police to a nineteenth-century democratic vision.

In fact, local police could not possibly accommodate the increasingly national scope of criminal syndicates. Even before the Civil War, private detective agencies lent their expertise to assist the fledgling municipal police in capturing outlaws like Jesse James and Butch Cassidy, whose notorious crimes spanned city and state boundaries. ${ }^{33}$ The most famous of these was the Pinkerton National Detective Agency, founded in 1855 by Allan Pinkerton, a Scottish immigrant living in Chicago. ${ }^{34}$ Prior to the Civil War, the agency also served as a labor spy service, providing businesses with "spotters" who disguised themselves as workers to detect lazy or dishonest employees. ${ }^{35}$ Gaining expertise and national prominence in the Civil War, the Pinkertons assisted the Chief of the Secret Service by infiltrating the confederate ranks. ${ }^{36}$ After the war, labor conflict reached a heightened pitch. Employed essentially as spies for the state, the Pinkertons used informers and undercover agents to undermine union strike efforts and assist the government in labor discipline. ${ }^{37}$ Hired initially by private businesses, the Pinkertons often

\footnotetext{
so VILA \& MORRIS, supra note 23, at 26.

31 See Robert M. Fogelson, Big-City Police 15-16 (1977).

32 Alexis de TOCQUeVIlle, Democracy in AMERICA 96 (J.P. Mayer ed., 1969).

33 Willlam J. Bopp \& Donald O. Schultz, Principles of American Law ENFORCEMENT AND CRIMINAL JUSTICE 55-57 (1972).

${ }_{34}$ Robert P. Weiss, Private Detective Agencies and Labor Discipline in the United States, 1855-1946, in Social History of Crime, Policing AND Punishment 357, 358-62 (Robert P. Weiss ed., 1999).

${ }^{35} I d$, at 360 .

36 Id. at 358.

${ }^{37}$ Id. at 362. For a discussion of the role of the Pinkertons in the Homestead Strike of 1892, see David MONTGOMERy, The FALL OF THE House OF LABOR: THE
} 
ended up working with local police and federal officials in staging undercover operations. ${ }^{98}$

Up until the end of the nineteenth century, police served a far broader social role than in our modern conception. They bore much of the burden of social welfare, housing the homeless, and caring for the poor during that early period. ${ }^{39}$ By the 1890 s, however, the police were engaged less actively in the problems of every-day life. They abandoned care for the homeless and focused almost exclusively on crime control. ${ }^{40}$ Historian Eric Monkkonen argues that this shift precipitated a greater distrust, estrangement, and anonymity between the city residents and their police. ${ }^{41}$ During this same period, police organization mirrored the decentralized nature of urban American politics. Aldermen or city councilmen nominated police chiefs for their own wards. ${ }^{42}$ Throughout the country the police gradually allied with corrupt city politicians and grew increasingly ineffective at managing the escalating crime rates. ${ }^{43}$ This was in part due to the steep increase in urban crime, combined with the forces' poor organization and rudimentary equipment. ${ }^{44}$ But it also resulted from a kind of deliberate tolerance, and at times, an outright acceptance of vice. ${ }^{45}$ Ward bosses depended on police to manipulate the polls, provide patronage jobs, and grant favors for constituents. Police officers and their supervisors in turn were beholden to politicians for their jobs and coveted promotions. ${ }^{46}$ Officers in New York, for example, paid regular fees to Tammany leaders, which they then recouped by extorting money from saloons, gambling houses, and brothels. $^{47}$ Thus, city politics operated in the shadow of this uneasy alliance between police, politicians, and the underworld. ${ }^{48}$

\footnotetext{
WORKPLACE, THE STATE, AND AMERICAN LABOR ACTIVISM, 1865-1925, at 37-38 (1993).

${ }^{38}$ See, e.g., Speiden v. State, 3 Tex. Ct. App. 156 (1877). Between the years of 1892 and 1910, the Pinkertons opened fifteen new branch offices, worked increasingly with state authorities, and served basically as spies for the state. See Weiss, supra note 34 , at 362.

39 MonkKonen, POLICE IN URBAN AmERica, supra note 19, at 150 .

10 Id. at $156-57$.

${ }^{41}$ See id. at 157-61.

42 WALKER, supra note 28, at 9.

${ }^{43}$ See Fog.lson, supra note 31, at 1-12.

${ }^{44}$ Id.

45. Id.

46 Jay StUart Berman, Police administration and Progressine Reform: THEOdORE ROOSEVElT AS POLICE COMMISSIONER OF NEW YORK 17-20 (1987).

47 See AsTOR, supra note 16, at 57-60.

*8 See Mark H. Haller, Historical Roots of Police Behavior: Chicago, 1890-1925, in Police, Prison, AND Punishment 323, 330-34 (Kermit L. Hall ed., 1987); see also FOGELSON, supra note 31 , at $5-10$.
} 
Because police depended on revenue from crime just as the politicians depended on votes and fees from the police, officers did not attempt to suppress crime or vice; they regulated it. ${ }^{49}$ Police in Chicago, for example, facilitated illicit activity by dividing their beats between warring gangs of pickpockets. They staged arrests so that angry victims would feel vindicated, and then promptly released the culprit for a small fee. ${ }^{50}$ To further this symbiotic relationship, detectives developed a network of informers and maintained extensive relationships with the underworld. As historian Mark Haller observed about the Chicago police at the turn of the century, "[e]ven conscientious detectives were so involved with the underworld that there was only a thin line between being guardians against crime and partners with criminals." ${ }^{51}$

The situation did not escape the vigilance of the progressive reform movement. ${ }^{52}$ In fact, the police-an all too concrete symbol of the success of immigrant values over middle-class mores-became one of the central objects of the movement's attention. ${ }^{53}$ Not only were detectives and officers tolerating vice and crime, they were lining their pockets with the proceeds. As a result, policemen proved ineffectual at preventing other sorts of street crimes. They spent

49. FOGELSON, supra note 31, at 32.

50 Haller, supra note 48 , at 332.

Id at 331

52 See WALKER, supra note 28, at 65-66; see also BERMAN, supra note 46, at 2-14; FOGELSON, supra note 31, at 2-12. In New York City, the reform movement managed to set up an investigative committee chaired by Republican Senator Clarence Lexow to examine police corruption. See BERMAN, supra note 46, at 31-32. The report, together with mounting public concern, culminated in the election of the antiTammany mayor William Strong. Id. Success, however, proved short-lived. Id. Like most cities, corruption persisted in police and municipal government well into this century. Id.

53 The historiography of the progressive era reform movement is vast, and historians disagree about the precise meaning of the term. Among the contending overviews are Allen F. DAVIS, SPEARHEADS OF REFORM: THE SOCLAL SETTLEMENTS AND the Progressive Movement, 1890-1914 (1968); Robert Weibe, The SEarch for ORDER (1967); RICHARD HOFSTADTER, THE AGE OF REFORM (1955). More recent scholars have approached progressivism from social and cultural angles adding countless wrinkles, nuances, and critiques of the earlier histories. See, e.g., GEORGE Chauncey, Gay New York: Gender, Urban Culture, and the Making of the GaY MALE WORLD, 1890-1940 (1994); Linda GordON, Heroes OF THEIR OWN LIVES: THE POlitics ANd History OF FAMily Violence, Boston, 1880-1960 (1988); Alice KesslerHarris, OUT to WORK: A History Of WaGe-Earning WOMEN IN THE UNITEd STATES (1982). For an ambitious attempt to synthesize the material and distill some common elements of the era's reform impulse, see Daniel T. Rodgers, In Search of Progressivism, 10 REvS. IN AM. HIST. 113, 113-32 (1982). For specific discussions of progressivism and corrupt urban politics, see JOHN D. BUENKER, URBAN LIBERALISM AND Progressive Reform (1973); ZANe Miller, Boss CoX's Cincinnati (1968). 
their days at the local saloon, tavern, and brothels, anywhere but their respective beat. ${ }^{54}$ Beginning around the turn of the century, reformers both inside and outside of the department sought to purge the police of such corruption and remove the force from the taint of the lower class immigrants' questionable moral compass. ${ }^{55}$ In the spirit of the times, reformers pushed for greater professionalism. ${ }^{56}$ Following the example of August Vollmer, the Chief of Police in Berkeley, California, reformers advocated more scientific methods of crime detection, standardized admission requirements, formal education, centralization, improved technology, and higher standards of policing. ${ }^{57}$

Meanwhile, businesses took matters into their own hands, hiring private detectives to protect their interests. Government officials joined forces only after private detectives had employed covert tactics to uncover the crime..$^{58}$ For instance, in Wisconsin, an employer, suspecting that a disgruntled employee whom he recently fired posed a threat, hired a detective to seek out the employee and try to embroil him in a scheme to blow up his former place of business. ${ }^{59}$ The private detectives informed the police only after they had encouraged the employee to buy dynamite and other explosives. ${ }^{60}$ Businesses also hired private detective agencies to uncover crime and city corruption that threatened their chances at prized government contracts. In Ohio, a manufacturer's association hired the Burns Detective Agency to root out corruption in the Columbus city government. ${ }^{61}$ The private detectives did not call the prosecuting

${ }^{54}$ WALKER, supra note 28 , at 10,24 .

55 See FOGELSON, supra note 31, at 67-92. Fogelson lists a number of reform initiatives. He argues that reformers sought to impose a military structure on the police, to centralize their operations, and remove the force from local control. See id.

${ }^{56}$ As a part of the general faith in scientific methods during the progressive era, reformers uniformly sought to professionalize many different areas of American culture. For histories of professionalization in the progressive era, see REGINA G. Kunzel, Fallen WOMEN, Problem Girls: UNMARried MOTHERS AND THE Professionalization OF SOClal WORK, 1890-1945 (1993); Thomas Haskell, The Emergence of the Professional Social Sciences: The American Soclal Science ASSOCLATION AND THE NINETEENTH-CENTURY CRISIS OF AUTHORITY (1977); DOROTHN' Ross, THE ORIGINS OF THE AMERICAN SOClal SCIENCES (1991); BURTON BLEDSTEIN, THE Culture of Professionalism (1976).

${ }_{57}$ WALKER, supra note 28, at 130; see also JOHNSON, supra note 16 , at $70-71$.

${ }^{58}$ See Weiss, supra note 34 , at 358-62.

${ }^{59}$ Koscak v. State, 152 N.W. 181, 183 (Wis. 1915).

in Id.

${ }^{61}$ As an illustration of the permeable nature of private and public policing at this time, Harvey M. Dougherty, the head of the Secret Service during the Harding administration, appointed William $\mathrm{J}$. Burns, the founder of the private detective agency involved in many of these early entrapment cases, chief of the Bureau of 
attorney until they had installed a dictograph in a hotel room where the staged bribe was set to take place. ${ }^{62}$

After 1920, police reform enjoyed some modicum of success. ${ }^{69}$ Centralized bureaucracies began to replace decentralized precincts, which wrested some control from ward politicians. Reformers managed to impose certain educational standards and routine training. ${ }^{64}$ The success of police reform tacked with the ebb and flow of municipal reform in general. Formal authority, however, did not always correspond to actual power, and ward leaders retained a large degree of power well into the century even as they grew wary of displaying it with the abandon of earlier decades. ${ }^{65}$ Beginning in the early 1900 s, reformers in some states did succeed in organizing state police forces. In the nineteenth century, only Massachusetts and Texas had state police. ${ }^{66}$ By 1923, fifteen states (mostly northern industrial states) established similar state law enforcement bodies. ${ }^{67}$ One historian called these new state police forces an "unprecedented extension of government into the lives of ordinary citizens." ${ }^{68}$

Perhaps even more significant than centralization, professionalization, privatization, and state control, was the growing influence of the federal government in law enforcement. In theory, federal law enforcement dated back to the Federal Judiciary Act of 1789. ${ }^{69}$ Among other things, the Act gave federal courts exclusive jurisdiction over "offences cognizable under the authority of the United States." ${ }^{\prime 70}$ Leaving the term undefined, Congress enumerated several specific federal offenses the following year in the Crimes Act

Investigation in 1921. See Weis, supra note 34, at 365-71. Later, Burns worked with his old agency in prosecuting various high profile syndicalism cases, including the well-known case of Charles Ruthenberg in April 1923. Id. In that case, the defense attorney accused the government of using the Burns agency to plant documents that would support its case of espionage. Id.

${ }^{62}$ Diegel v. State, 1911 WL 680 , at $* 4, * 5$ (Ohio Cir. Oct. 17, 1911). The same agency was involved in efforts to root out city corruption in New Jersey and Maryland. See State v. Dougherty, 86 N.J. 525, 531-33, 93 A. 98, 101 (N.J. Sup. Ct. 1915); Hummelshime v. State, 93 A. 990 (Md. 1915).

See JOHNSON, supra note 16 , at 105-15.

64 Id. at 105.

${ }^{63}$ See FOGELSON, supra note 31, at 110-12.

66 JOHNSON, supra note 16 , at 156.

${ }^{67}$ See id. at 155-61.

68 Wilbur R. Miller, Police Authority in London and New York City, 1830-1870, in Social. History of CRime, Policing and Punishment 335 (Robert P. Weiss ed., 1999).

1 Cong. Ch. 20, 1 Stat. 73 (1789).

70 Dwight F. Henderson, Congress, Courts, and Criminals: The Development OF FEDERAL CRIMINAL LAW, 1801-1829, at 5 (1985). 
of $1790 .{ }^{71}$ Congress added crimes to the list throughout the century, but the number and scope of these federal crimes remained fairly circumscribed until the end of the century. ${ }^{72}$ The Judiciary Act also created the office of the United States Marshall, the first federal law enforcement agency. ${ }^{79}$ The United States Marshals Service grew increasingly responsible for bringing some modest sense of order to the relatively ineffectual law enforcement on the new frontier. ${ }^{74}$

By the end of the nineteenth century, the number of federal crimes and the reach of federal criminal law had expanded. Federal law enforcement, however, developed or evolved haphazardly within different branches of government, in response to the advent of different crimes. For example, when Congress made mail fraud a crime, the post office developed agents who were eventually organized as the Division of Postal Inspectors in $1875 .^{75}$ Similarly, the Treasury Department developed special agents assigned to both the Customs Service and the Bureau of Internal Revenue to investigate fraud and counterfeiting. ${ }^{76}$ As crime grew more national in scope, each of these new enforcement teams developed ties with the other, and, more importantly, with municipal and state police departments. ${ }^{\text {" }}$ For instance, in response to the Comstock Law of $1873{ }^{78}$ which outlawed sending obscene materials through the mail, federal postal inspectors developed intricate networks with local police and exchanged information they received on state crimes for help with federal prosecutions. ${ }^{79}$

That same year, the government created the Secret Service to protect the newly standardized currency. ${ }^{80}$ At first, the agency consisted of a few private detectives, who quickly developed a fairly sophisticated system of informers and stool pigeons to pursue the increasingly rampant and extensive counterfeit rings. ${ }^{81} \quad$ By the late nineteenth century, however, the Secret Service became a kind of allpurpose federal police department, lending its expertise to almost

it 1 Cong. Ch. 9, 1 Stat. 112 (1790).

72 See HeNderson, supra note 70 , at 5-7.

${ }^{73}$ VILA \& MORRIS, supra note 23, at 67.

if PRASSEl, supra note 11 , at 221.

${ }_{75}$ JOHNSON, supra note 16 , at 75,78 .

${ }^{76} \mathrm{Id}$.

7 See id. at 75-87.

7842 Cong. Ch. 258, 17 Stat. 598 (1873).

79 JOHNSON, supra note 16 , at $79-80$.

${ }^{80} \mathrm{Id}$. at 81 .

${ }^{81}$ Id. at 83-85. 
any federal agency that needed it. ${ }^{82}$ However, in 1908 , responding to some threatening investigations into the suspect behavior of several individual congressmen, Congress restricted the use of the Secret Service to policing counterfeit currency and protecting the president. $^{83}$ In a blatant act of defiance, Attorney General Charles Bonaparte responded to this display of self-interest by singlehandedly creating the Bureau of Investigation within the Department of Justice. ${ }^{84}$ Theodore Roosevelt ordered the Secret Service to transfer eight agents to the new Bureau, soon to be renamed the Federal Bureau of Investigation. ${ }^{85}$

As legal historian Lawrence Friedman noted, "if the central government swells and bloats, that must have consequences" did just that. In the first few decades of the twentieth century, Congress stretched its new regulatory wings. In 1913, Congress enacted the first real income tax, which drew a whole new set of crimes and prosecutions in its wake. ${ }^{87}$ In addition, it set in motion a wide variety of regulatory statutes, including the Mann Act, ${ }^{88}$ which prohibited the transport of women across state lines for immoral purposes, thereby increasing demand for federal law enforcement. ${ }^{89}$ World War I spawned yet more federal legislation, which in turn, escalated the need for more organized and powerful federal police. The Bureau of Investigation, the Secret Service, and the Postal Inspectors grew in numbers and force after Congress passed the Espionage Act of $1917^{90}$ and the Sedition Act of 1918. ${ }^{91}$ Following the

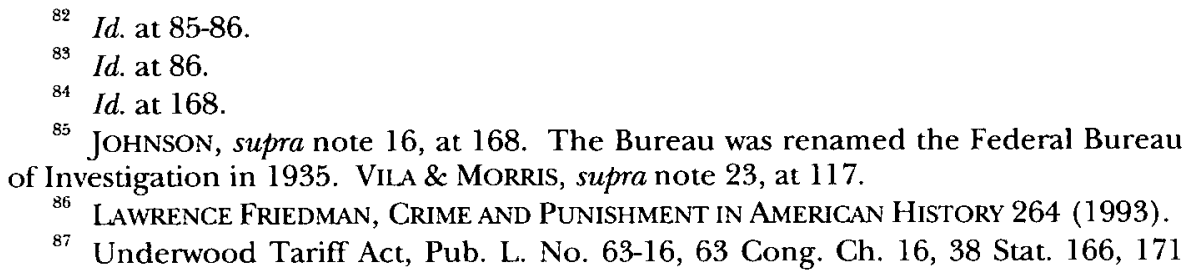

${ }^{85}$ JOHNSON, supra note 16 , at 168 . The Bureau was renamed the Federal Bureau of Investigation in 1935. VILA \& MORRIS, supra note 23, at 117.

86 LaWrence Friedman, Crime and Punishment in AMERICAN History 264 (1993).

${ }^{87}$ Underwood Tariff Act, Pub. L. No. 63-16, 63 Cong. Ch. 16, 38 Stat. 166, 171 (1913)

${ }^{88}$ Pub. L. No. 61-277, 61 Cong. Ch. 395, 36 Stat. 825 (1910).

${ }^{89}$ See supra note 87 . The progressive era witnessed an unprecedented increase in the federal government's regulatory power. See WALKER, supra note 28, at 136-37. Other acts included an act preventing income tax fraud; the Harrison Act, making it a crime to import, manufacture and dispense certain drugs; and the Dyer Act, making it a crime to drive a stolen vehicle across state lines. See Friedman, Crime And PUNISHMENT, supra note 86, at 354-57. For a general discussion of the extension of state power in to areas of everyday life, see ANDREW J. POLSKY, THE RISE OF THE THERAPEUTIC STATE 65-136 (1991).

${ }_{90}$ Pub. L. No. 65-24, 65 Cong. Ch. 30, 40 Stat. 217, 219 (1917) (providing sentences for aiding the enemy, obstructing recruitment, and mailing seditious literature).

${ }^{91}$ Pub. L. No. 65-150, 65 Cong. Ch. 75, 40 Stat. 553 (1918) (making it a crime to write, publish, or utter disloyal or abusive language about the government). 
War, the infamous "Red Scare" solidified the power and intensified the techniques of federal law enforcement. ${ }^{92}$ In a gesture whose historical import probably exceeded even its author's imagination, Attorney General A. Mitchell Palmer named J. Edgar Hoover head of the General Intelligence Division of the Department of Justice. ${ }^{93}$

Perhaps the single most important catalyst in creating a federal law enforcement presence and linking municipal police to a broad national agenda was the advent of national prohibition. ${ }^{94}$ The Eighteenth Amendment, which went into effect in 1920, and its statutory counterpart the Volstead Act, ${ }^{95}$ passed the year before, gave federal agents license to intervene in unprecedented ways. ${ }^{96}$ National prohibition promoted and deepened the relations between local, state, and national law enforcement as federal officials worked in conjunction, and shared information, with local police. ${ }^{97}$ Thus, prohibition institutionalized the federal wing of law enforcement while simultaneously increasing the scope and creativity of its undercover tactics. ${ }^{.8}$

During prohibition, the blurring of this side and that side of the law, prevalent in progressive-era urban machine politics, took on

92 JOHNSON, supra note 16 , at 171-72.

93 Id. at 171 .

94 See generally Kenneth M. Murchison, Federal Criminal Law Doctrine: The ForgotTEN INFLuence OF NATIONAL Prohibition 1-22 (1994). The movement for national prohibition actually began a century earlier. In 1826, temperance workers formed the American Society for the Promotion of Temperance. Id. at 4. In the $1840 \mathrm{~s}$, reformers concentrated increasingly on moral persuasion rather than legislation. Id. In the following decade, however, leaders of the temperance movement pushed once again for prohibitory legislation. They achieved their first success in Maine in 1851, but many state courts overruled temperance legislation and by 1869 only six states had extant prohibitory laws. Id. at $4-5$. In the second half of the nineteenth century, reformers formed the Prohibition party, which helped defeat James G. Blaine in the 1884 presidential election. In 1874 , the movement gathered momentum when evangelical reformers formed the Women's Christian Temperance Union. Id. at 5. In 1893, the Anti-Saloon league emerged with a new pragmatic non-partisan agenda. $I d$. It ultimately succeeded in securing prohibitory laws in a majority of states. $I d$. at 6 . In the early twentieth century, the league succeeded in building a political base, lobbying for national anti-liquor regulations, and ultimately pushing for national prohibition. Id. at $6-7$.

${ }_{95}$ Pub. L. No. 66-66, 66 Cong. Ch. 85, 41 Stat. 305 (1919).

${ }_{96}$ Mark Keller, Alcohol Problems and Policies in Historical Perspective, in LAw, Alcohol, and Order: Perspectives on National Prohibition 159 (David Kyvig ed., 1985).

${ }_{97}$ See JoHnson, supra note 16 , at 143-45; see also Wickersham Commission, Enforcement of the Prohibition Laws of the United States: Message from the President of the United States 37-43 (1931).

${ }_{98}$ WALKER, supra note 28 , at $139-40$. 
federal dimensions. ${ }^{99}$ The examples could, and have, produced a great number of contemporary and historical accounts. For the purposes of this article national prohibition gave new inspiration to a process that was already well underway. It drew local and national police closer together while issuing broad licenses to enforcement officials to pursue increasingly intricate undercover investigations. For example, in an attempt to catch potential criminals in the act, the Prohibition Bureau imported its own liquor from Canada to retail to bootleggers. ${ }^{100}$ In an even an more flagrant use of illicit means to halt the mass consumption of alcohol federal officials operated their own speakeasy, called the Bridge Whist Club, in New York City and openly sold liquor to any willing patron. ${ }^{101}$ Izzy Einstein and Moe Smith, two of the more notorious prohibition agents, drew national media attention when they topped the records in prohibition arrests by disguising themselves as gravediggers, fishermen, vegetable vendors, and musicians to infiltrate the underworld. ${ }^{102}$

\section{History OF THE ENTRAPMENT DEFENSE}

Entrapment caught the attention of judges and academics in the context of this rapidly transforming system of law enforcement. It gradually took hold amidst the increasingly interrelated and invasive tactics of both federal and local police. While it is impossible to locate an exact date-a moment in time when the nature of policing shifted in some critical way-entrapment emerged as law enforcement itself had grown so remote from the original ideal discussed by Tocqueville in mid-century as to be virtually unrecognizable. Historian Kenneth Murchison argues that entrapment was a judicial response to national prohibition. ${ }^{103}$ Prohibition was clearly a key factor in the consolidation of this new defense, and it may, indeed, have been critical in causing the Supreme Court to recognize a universal federal entrapment defense. By looking at the state and federal cases both before and after national prohibition in the context of the history of law enforcement in general, it becomes clear that entrapment was not only a reaction to prohibition, but also a cumulative response to the changed nature of government. Entrapment profoundly altered the relationship

99 See Murchison, supra note 94, at 43.

${ }^{100} I d$.

101 Id.

102 Id.; see also Charles MERTz, ThE DRy Decade 136 (1931). Izzy Einstein and Moe Smith were ultimately dismissed from the force when their widespread notoriety undermined their usefulness as undercover agents. Id. at 137.

${ }^{103}$ MURCHISON, supra note 94 , at $42-46$. 
between officials on all levels of government and the average citizen. This section of the article posits that entrapment has gone through three different stages: first, the nineteenth-century private law model of entrapment; second, the emergence of the defense as a means of exonerating criminals who were "created" by the state; and finally, the academic push for an objective model of entrapment designed to deter government misconduct. ${ }^{104}$

No state or federal court recognized entrapment as a valid defense prior to 1870 . State courts did develop and apply a common law consent doctrine based on private law notions of contract that provided a prototype for the later developed entrapment doctrine. The doctrine of consent dictates that if force (or lack of consent) is an element of a crime and the victim cooperates with authorities in capturing the perpetrator, then courts cannot convict because the very act of entrapping the criminal negates a material aspect of the crime. ${ }^{105}$ In Eggington's Case, ${ }^{106}$ an English decision from 1801, a band of robbers planned to rob a manufactory near Birmingham. They contacted Phillips, a servant and watchman of the business, to gain valuable assistance in their plan. Phillips apparently agreed to help but promptly reported the illicit plot to the proprietor, Mr. Boulton. Boulton instructed Phillips to continue with the plan, contacted authorities, and stood in wait as the unsuspecting robbers entered his place of business. The court noted that when a property owner cooperates with authorities in capturing a burglar, he essentially assents to the entry, thereby negating trespass, an essential element of the crime. All justices agreed, however, that knowledge of an impending crime did not constitute consent to its commission. Because Boulton did nothing to encourage the crime, he did not assent to the entry, and the robbers were guilty as charged. ${ }^{107}$

American courts used this consent doctrine in some form or another throughout the early part of the century. ${ }^{108}$ Prior to the Civil War, courts in the South used Eggington's Case and similar precedents to enforce various laws related to slavery. In 1832, for instance, a South Carolina court upheld the conviction of a prisoner charged with stealing a slave. ${ }^{109}$ The defendant approached someone else's

${ }^{104}$ I have not put dates on these periods because there is significant overlap and the shift occurs at different times in state and federal courts.

${ }^{105}$ See 1 Bishop, Criminal LaW $\$ 262$ (5th ed. 1872).

106 East's P.C. 666 (1801).

${ }^{107}$ Id. at 667.

108 See 1 BISHOP, supra note 105.

109 State v. Covington, 18 S.C.L. 569 (1 Bail. 1832). 
slave and attempted to persuade the slave to run away with him. ${ }^{110}$ The slave reported the story to his master who contacted authorities and instructed the slave to act as if he were going to comply. ${ }^{111}$ The slave owner and the local police stood in wait and ultimately captured the thief in the act. ${ }^{12}$ The court held, much like the earlier English case, that the complicity of the slave owner does not negate the element of "taking by force" because an attempt to detect a crime already in progress does not constitute assent. ${ }^{119}$ There was no meeting of the minds because the thief did not know that the owner had agreed. ${ }^{114}$ Thus, the court held the victim did not agree to have his property taken and the defendant was guilty as charged. ${ }^{115}$

After the Civil War, courts continued to draw on this line of precedent, especially in cases involving burglary. As with the earlier cases, courts tended to find a way around the formal consent doctrine by manipulating the idea of assent or "the meeting of the minds," which is common in contract law. Thus, some courts, following the formal law of contract and agency, concluded that if a decoy was employed by the police to participate in the burglary with the consent of the owner, there was no burglary. ${ }^{116}$ Some courts dismissed the consent defense by insisting that an owner, who knows about a crime in advance and informs authorities, has not given his assent to the crime-an act which would negate an element of the trespass. ${ }^{117}$ Either way, until the very end of the century, most state courts would not excuse the defendant merely because the detective initiated, induced, or precipitated the events if the prosecution could prove that all the formal elements of the crime were present. ${ }^{118}$

The holding in Board of Commissioners of Excise v. Backus ${ }^{119}$ further

$\begin{array}{ll}{ }_{110} & I d . \\ { }_{111} & I d . \\ { }_{112} & I d . \\ { }_{114} & I d . \\ { }_{115} & I d .\end{array}$

See State v. Covington, 18. S.C.L. at 569; see also State v. Geze, 8 La. Ann. 52 (La. 1853) (relying on the same precedent to affirm a conviction for a violation of an ordinance preventing the sale of intoxicating liquor to slaves without the owner's consent); Whaley v. State, 11 Ga. 123 (Ga. 1852) (holding similarly with regard to a defendant convicted of attempting to steal a slave); State v. Anone, 11 S.C.L. 27 (1 Nott \& McC. 1819) (holding similarly with regard to the 1817 Act to prevent illicit trading with slaves).

${ }_{116}$ See, e.g., People v. Collins, 53 Cal. 185, 186-87 (Cal. 1878); Speiden v. State, 3 Tex. Ct. App. 157 (1877).

117 See, e.g., Allen v. State, 40 Ala. 334, 341 (Ala. 1867); Smith v. State, 43 Tex. 103 (Tex. 1875).

118 State v. Jansen, 22 Kan. 498 (Kan. 1879).

11929 How. Pr. 33 (N.Y. Sup. Ct. 1864). 
illustrates how courts used private law doctrines to decide the earlier cases involving decoys and informers. In that case, the Board of Commissioners of Excise in Onandaga County employed an informer to buy liquor from Backus, who was ultimately convicted of violating a state prohibition statute. ${ }^{120}$ The Commissioners then sued to recover the penalty. ${ }^{121}$ The defense argued that the plaintiffs could not recover because their cause of action was based on an immoral or illegal act. ${ }^{122}$ To support this proposition, the defense invoked a common contract principle: courts will not lend their aid in enforcing an agreement which has, as its ultimate object, the violation of the law or public policy, or the perpetration of a fraud upon a third party. ${ }^{123}$ The court reasoned that because Backus was guiltier than the Commissioners, the two were not in pari delicto, ${ }^{124}$ and the court ought not shield the more guilty party from the consequences of his act. ${ }^{125}$ In an extended coda, the court praised the law enforcement techniques used not only to uncover violations of excise laws but also to root out mail fraud and counterfeit rings. ${ }^{126}$

At mid-nineteenth century, courts primarily expressed their approval of law enforcement tactics involving deceit and trickery to catch criminals. In 1857, for instance, Illinois authorities hired a witness to buy liquor from an individual suspected of violating state prohibition laws. ${ }^{127}$ In dismissing an attempt at the entrapment defense, the court admonished:

If men who voluntarily or otherwise become acquainted with the secret brothels, gambling and drinking hells with which our cities and villages are sometimes overrun, and our neighbors and our children are corrupted and ruined, are to lose their character for veracity, and are to be denounced as informers and spies, for seeking out and bringing these evil practices to light, then are our hopes of protection slight indeed. ${ }^{28}$

By the late $1870 \mathrm{~s}$ and $80 \mathrm{~s}$, this high praise for covert operations, was glaringly absent from court decisions. While clinging to the language of contract law in disposing of the cases, many courts went

\footnotetext{
${ }^{120}$ Id.

121 Id.

122 Id.

${ }^{123} I d$.

${ }^{124}$ "Pari delicto" literally translated means "in equal fault." Gil_BERT's LAW DICTIONARY 233 (pocket verstion 1997).

${ }^{125} I d$

${ }^{126} 29$ How. Pr. 33.

${ }^{127}$ President of the Town of St. Charles v. Peter O'Mailey, 18 Ill. 407 (IIl. 1857).

${ }^{128}$ Id. at 414; see also Bd. of Comm'rs of Excise v. Backus, 29 How. Pr. 33 (N.Y. Sup. Ct. 1864).
} 
beyond the rubric and denounced the involvement of the state in their overzealous pursuit of undercover investigations and prosecutions. ${ }^{129}$ In Michigan, a lawyer was convicted of taking public records from a courtroom. ${ }^{130}$ He had asked his friend, a police guard, to leave the door of the courtroom open. ${ }^{131}$ The guard agreed, but quickly informed authorities. ${ }^{132}$ The stool pigeon and the police stood by and arrested him as he shuffled through the papers. ${ }^{133}$ In reversing the conviction on the ground that the state consented to the entry, the court chastised:

[t] he course pursued by the officers in this case was utterly indefensible. Where a person contemplating the commission of an offense approaches an officer of the law, and asks his assistance, it would seem to be the duty of the latter, according to the plainest principles of duty and justice, to decline to render such assistance, and to take such steps as would be likely to prevent the commission of the offense [. $]^{134}$

Another court insisted that "it is one of the most disgraceful instances of criminal contrivance to induce a man to commit a crime in order to get him convicted that has ever been before us." 135 The judge continued by positing that "it is a diabolical business, which if not punishable probably ought to be." ${ }^{136}$ An Illinois court echoed this new sentiment: "[s]uch means and agents are more dangerous to the welfare of society than are the crimes they were intended to detect and the criminals they were to arrest."137

The state cases involving informers and decoys between the close of the Civil War and the turn of the century dealt with a large number of scenarios. They included, for example, prosecutions for burglary, ${ }^{138}$ violations of state excise laws, ${ }^{199}$ keeping houses of ill

129 See, e.g., People v. Morton, 11 P. 512, 513-14 (Utah 1886). There were a few exceptions, lingering praise for police zeal, and a sense that it is a guilty soul rather than the illicit act that matters. See, e.g., Varner v. State, 70 Ga. 745, 746 (Ga. 1883) ("One who is trying to steal the property of another is in the condition of a beast of prey, and it is as lawful to trap such a person as it is the beast of prey.").

Saunders v. People, 38 Mich. 218 (Mich. 1878).

131

$132 I d$

139 Id

134 Id. at 221-22

135 People v. McCord, 42 N.W. 1106, 1108 (Mich. 1889).

136 Id.

137 Love v. People, 43 N.E. 710, 711 (Ill. 1896).

138 E.g., Saunders v. People, 38 Mich. 218 (Mich. 1878).

${ }^{139}$ E.g., Rater v. State, 49 Ind. 507 (Ind. 1875). 
fame,$^{140}$ and bribing public officials. ${ }^{141}$ By the 1920 s, the vast majority of state court defendants, who tried to escape conviction with the entrapment defense, were indicted under state and federal prohibition laws. While recognizing the theoretical validity of the defense, most courts refused to apply it. ${ }^{142}$ Other courts simply held that entrapment could never excuse defendants of violating liquor laws because the law itself did not require malicious intent. ${ }^{143} \mathrm{~A}$ minority of courts, however, either reversed or modified the sentence after severely criticizing the government's tactics. ${ }^{144}$

While courts encountered the defense with a good deal more frequency after 1920, the percentage of cases excusing a defendant on the ground that he was entrapped remained fairly constant throughout the early part of the century. ${ }^{145}$ What is significant, however, is the changed nature of the defense. Whether state courts reversed the conviction or not, by the turn of the century, state courts understood entrapment not in formal, contractual, and private law terms, but rather as a way of ascertaining voluntariness in the context of a prevalent and powerful state using increasingly sophisticated law enforcement techniques. In coping with covert law enforcement

${ }^{140}$ E.g., People v. Pinkerton, 44 N.W. 180 (Mich. 1889).

141 E.g., State v. Dudoussat, 17 So. 685 (La. 1895).

142 See, e.g., State v. Erlich, 282 P. 220 (Wash. 1929); State v. Lambert, 269 P. 848 (Wash. 1928); State v. Webster, 271 P. 578 (Idaho 1928); State v. Jarvis, 143 S.E. 235 (W. Va. 1929); Claxton v. People, 257 P. 347 (Colo. 1927); State v. R.A. Jackson, 249 P. 688 (Kan. 1926); Cosilito v. State, 151 N.E. 721 (Ind. 1926); State v. Driscoll, 239 P. 1105 (Kan. 1925); State v. Kirkbride, 241 P. 709 (Wyo. 1925); Clark v. People, 239 P. 1025 (Colo. 1925); State v. Abraham, 105 So. 50 (La. 1925); Clark v. State, 145 N.E. 566 (Ind. 1924); State v. Rippey, 122 S.E. 397 (S.C. 1924); State v. Boylan, 197 N.W. 281 (Minn. 1924); Plue v. People, 193 P. 496 (Colo. 1920); Reim v. State, 280 P. 627 (Okla. Crim. App. 1929); Terrell v. State, 166 N.E. 8 (Ind. Ct. App. 1929); Brewer v. State, 123 So. 86 (Ala. Ct. App. 1929); Miller v. State, 260 P. 511 (Okla. Crim. App. 1927); People v. Bradford, 258 P. 660 (Cal. Ct. App. 1927); People v. Harris, 251 P. 823 (Cal. Ct. App. 1926); People v. Schell, 240 Ill. App. 254 (Ill. App. Ct. 1926); Wilks v. State, 106 So. 681 (Ala. Ct. App. 1925); Mullikan v. State, 240 P. 1099 (Okla. Crim. App. 1925); People v. Norcross, 234 P. 438 (Cal. Ct. App. 1925); Bartholomew v. Commonwealth, 258 S.W. 677 (Ky. Ct. App. 1924).

${ }_{143}$ E.g., French v. State, 115 So. 705 (Miss. 1928); State v. Broaddus, 289 S.W. 792 (Mo. 1926).

144 E.g., State v. McKeehan, 279 P. 616 (Idaho 1929); State v. Decker, 14 S.W.2d 617 (Mo. 1929); State v. Johnson, 207 N.W. 216 (S.D. 1926); Sherwood v. State, 279 P. 916 (Okla. Crim. App. 1929); People v. Schell, 240 Ill. App. 254 (Ill. App. Ct. 1926).

${ }^{145}$ In arguing that it was national prohibition that created the entrapment defense, Kenneth Murchison examines primarily federal cases and thus fails to note the early state versions of entrapment. While it may be true that courts in states that resisted prohibition tended to use the defense more liberally during those years, the infrastructure of the defense pre-existed prohibition. See MURCHISON, supra note 94, at $22-46$. 
operations, courts stretched contract law to its extreme. The consent doctrine proved inadequate because, in theory, any defendant could argue that if the government used decoys, informers, or traps of any sort it consented to the crime. One court tried to circumvent this problem. ${ }^{146}$ Confronted with a case in which a lawyer bribed public officials to give him the indictments of a business partner and friend, the court analyzed intricate legal contortions to distinguish the earlier consent cases. ${ }^{147}$ The court insisted that even though the officials willingly handed over the indictments to catch the defendant in the act, there was no consent because there is a difference between public and private ownership of property. ${ }^{148}$ If a private party delivers property to someone voluntarily, then there can be no trespass. If, however, the property belonged to the state and the state cannot consent through individual officers, the element of trespass remained unmarred by the district attorney's voluntary participation. ${ }^{149}$ Not surprisingly, entrapment soon outgrew its increasingly ill-suited roots in private law concepts. ${ }^{150}$

Early traces of this shift can be found in the last few decades of the nineteenth century. Courts edged toward a new understanding of the law that ultimately evolved into the entrapment defense. Reacting with increasing outrage at police tactics, the courts began to recognize, albeit in superfluous language not directly related to the holding of the case, that contract principles could not comprehend the concept they wished to convey. Thus, a Michigan court concluded that it is the role of the state "to tend to the elevation and improvement of the would-be criminal, rather than to his further debasement." ${ }^{151}$ In another case, the same court noted that the fact that a defendant had a bad, immoral character could not justify luring him into a specific crime. ${ }^{152}$

${ }^{146}$ People v. Mills, 70 N.E. 786 (N.Y. 1904).

147 See id. at 789-91.

148 See id. at 791, 788-89.

149 Id.

150 Even in that case, Judge O'Brien offered a dissent that focused primarily on the voluntariness of the defendant's actions rather than ideas of contract and property, which are more properly suited to private complaints. Thus, he reasoned that the conviction should be vacated because there is a difference between a contemplated crime and unlawful intentions and the state unjustly "stimulat[ed] unlawful intentions." Id. (O'Brien, J., dissenting).

151 Saunders, 38 Mich. at 222.

152 People v. McCord, 42 N.W. 1106, 1109 (Mich. 1889). This language may well have been a part of the new progressive reform discourse. Historians have noted, in general, a shift from a punitive to a rehabilitative model in charitable movements, jurisprudence, and reform rhetoric in general. See, e.g., KUNZEL, supra note 56, at 1-9; LORI D. GINZBERG, WOMEN AND THE WORK OF BENEVOl.ENCE: MORALITY, POlitics, AND 
In the late 1890s in Momence, Illinois, a city councilman hired a private detective firm to prevent a string of robberies that seemed to be plaguing the area. ${ }^{153}$ The detective came to town and befriended some local boys by lavishing them with money and treating them to expensive cigars and liquor. ${ }^{154}$ After weeks of feigned friendship, the detective convinced the defendants to join him in robbing an office. ${ }^{155}$ The appeals court reversed the burglary conviction and firmly noted that this foreign detective's "efforts were not directed to the arrest of criminals, but his mental powers and robust health, with the use of money, were directed towards an effort to make criminals of these young men." 156 The court commented, "with plenty to drink and smoke and eat at his expense, he sought to undermine and dazzle their mental and moral strength and lead them into the commission of crime." 157 The principles of contract and the consent doctrine played a minor role in the case. Rather, the malleability of human nature, the power of the state, and the state's endless resources to transform that nature and change the normal course of events by creating criminals impressed the court. ${ }^{158}$ The court noted " $[s]$ trong men are sometimes unprepared to cope with temptation and resist encouragement to evil when financially embarrassed and impoverished."159 A far cry from the moralistic musings of the New York court and its invocation of the unforgiving God of the old testament, this court began to develop traces of an entrapment doctrine which could encompass and define a new sort of individuality-one in which will and identity are no longer set in stone and the government itself can undermine an individual's resolve with its vast resources and awesome power. ${ }^{160}$

Class in the Nineteenth-Century United States (1990); Allen F. Davis, Spearheads for Reform: The Social Settlement and the Progressive Movement, 1890-1914 (1967).

153 Love v. People, 43 N.E. 710,711 (Ill. 1896).

${ }_{154}^{154}$ Id.

155 Id. at 712 .

${ }^{156}$ Id. at 711,713 .

${ }^{157}$ Id. at 711 .

${ }^{158} \quad$ Id. at 713

159 Id

${ }^{160}$ Some authors refer to this transformation as the product of romanticism. See Susanna L. Blumenthal, Law and the Creative Mind, 74 CHI.-KENT L. REv. 151, 157-58 (1998). Romanticism is an elusive term but it largely describes a shift from the sacred to the secular, an effort to reconfigure old norms in new ways. Thus, as one critic notes, romanticism constituted a broad cultural transformation designed to "save traditional concepts, schemes, and values which had been based on the relation of the Creator to his creature and creation, but to reformulate them within the prevailing two-term system of subject and object, ego and non-ego, the human mind 
By the 1920s, the old incarnation of entrapment, applicable only when the victim's consent vitiates a material element of the crime, virtually disappeared. In its place, state courts developed the modern version of the entrapment defense. This modern version focuses on whether criminal intent originated with the defendant. A successful defense proved that the government manipulated the defendant into committing a crime he would not otherwise have consummated. ${ }^{161}$ Thus, the courts evaluated the actions of government officials and their informers only insofar as they were relevant in determining the origin of criminal design. ${ }^{162}$ Toward the end of the 1920 s, one court approved of the following instruction on entrapment: where the defendant "had no criminal intent to violate the . . . [law], but is induced to become a law violator by reason of the arts and wiles of public officials to depart from the path of being a law-abiding citizen into the commission of crime." ${ }^{\text {"163 }}$ Another court clarified, "it is not proper, even during an investigation, to entice or persuade any one contrary to his own will or inclination, to violate the laws of this state; and if you find that the criminal design originated not with the accused, but was conceived in the mind of the officers of the state, and the accused was by persuasion or inducement lured into the commission of a criminal act," then it is proper to acquit. ${ }^{164}$ By the end of the prohibition decade, this language was quite common, and the question of entrapment had shifted almost entirely from a formal analysis of the elements of the crime and the evaluation of consent

or consciousness and its transactions with nature." M.H. ABRAMS, NATURAL. SUPERNATURALISM: TRADITION AND REVOLUTION IN ROMANTIC LITERATURE 13 (1971). My analysis complements this literature by illustrating how a stable individual possessing certain natural rights gave way to a more dynamic notion of the self. Thus, the idea that the human mind is a stable reflection of the natural world evolved into what some commentators have termed the romantic individual whose perception and interaction with others transforms both the individual and world around him. See id. This distinction has also been described in psychological terms. See Jessica Benjamin, Bonds of love: Psychoanalysis, Feminism, and the Problem of DOMINATION 3-50 (1988). In America, cultural historians refer to this shift as the movement from character to personality. See WARREN SUSSMAN, Culture AS HiSTORY: The Transformation OF American Society in THE TWEntieth Century 271-87 (1984).

${ }_{161}$ See, e.g., State v. Decker, 14 S.W.2d 617 (Mo. 1929); State v. McKeehan, 279 P. 616 (Idaho 1929); Plue v. People, 193 P. 496 (Colo. 1920); Koscak v. State, 152 N.W. 181 (Wisc. 1915); Reim v. State, 280 P. 627 (Okla. Crim. App. 1929); People v. Harris, 251 P. 823 (Cal. Ct. App. 1926); People v. Barkdoll, 171 P. 440 (Cal. Ct. App. 1918); People v. Conrad, 102 A.D. 566 (N.Y. App. Div. 1910); Wilcox v. People, 67 P. 343 (Colo. Ct. App. 1902).

${ }^{162}$ See supra note 161.

163 State v. Heeron, 226 N.W. 30, 31 (Iowa 1929).

164 State v. Lambert, 269 P. 848 (Wash. 1928). 
with old contract principles to a new focus on the malleability of human nature in light of the powerful state.

Even in burglary cases, where nineteenth-century courts had traditionally and uniformly employed the consent doctrine, twentieth-century judges phrased their opinions in terms of whether the government, together with its agents, informers, and stool pigeons "induce[d] the original intent." ${ }^{\text {165 }}$ In one case decided in 1915, Dr. Sanders, an Alabama state health officer, employed Avery, an applicant to practice medicine in the state, to help capture a suspect. ${ }^{166}$ Avery approached the defendant and offered him $\$ 100$ to raid Dr. Sanders's office and steal the medical examination results. ${ }^{167}$ The appeals court reversed the conviction, but not on the ground that Dr. Sanders consented to the burglary, but because the criminal intent originated with Dr. Sanders, an agent of the government, not with the defendant. ${ }^{168}$ Therefore, the government could not prosecute because it had implanted the intent in the defendant's mind. ${ }^{169}$

Not surprisingly, federal courts dealt with different sorts of crimes and thus, the entrapment defense arose in different contexts. The trajectory and development of the federal defense followed the state courts but lagged behind by about two decades. Regulating everyday life was largely the business of the states prior to the twentieth century; ${ }^{170}$ during this period the federal system rarely encountered the kinds of law enforcement tactics that drew the criticism and ire of state court judges. It makes sense, therefore, that entrapment simply would not come up in federal courts.

By the turn of the century, the entire body of federal criminal law was changing and expanding quite significantly. ${ }^{171}$ Most notably, Congress enacted a number of statutes that insinuated the federal

\footnotetext{
${ }^{165}$ Tones v. State, 88 S.W. 217 (Tex. Crim. App. 1905) (quoting Alexander v. State, 12 Tex. $540(1854))$.

${ }_{166}$ Adams v. State, 69 So. 357, 359 (Ala. Ct. App. 1915).

${ }_{167}^{167}$ Id.

${ }^{168} I d$.

${ }^{169}$ Id.; see also State v. Currie, 102 N.W. 875, 875-77 (N.D. 1905) (using similar language in burglary case); Dalton v. State, 39 S.E. 468, 468-69 (Ga. 1901) (employing this rubric in rejecting entrapment defense to a conviction for conspiracy to wreck a train).

${ }^{70}$ FRIEDMAN, supra note 86 , at $674-76$. The degree of state regulation of everyday life in the nineteenth century is itself a matter of some controversy. For an interesting critique of earlier notions of minimal, liberal nineteenth century state governments, see William Novak, The People's Welfare LaW and Regulation in NineteEnTH CeNTURY AMERICA (1996).

${ }^{171}$ See supra PART I; see also FRIEDMAN, supra note 86, at 264-67.
} 
government into what Lawrence Friedman calls the "life-area." In other words, Congress began using the commerce clause to regulate sex, morals, and daily conduct-areas that had previously occupied a predominantly local concern. Not only did the federal government venture into new territory, it also contributed to the growing number of victimless crimes, crimes against the public, or more particularly, crimes against public morality. ${ }^{173}$ All of these new crimes were difficult to detect without developing elaborate systems of information and links with the underworld. ${ }^{17}$

Significantly, in 1876 , Congress passed a statute ${ }^{175}$ which imposed criminal sanctions on anyone who sent obscene matter through the mail. ${ }^{176}$ Shortly thereafter, an agent of an anti-vice squad in St. Louis, known as "The Society of the Suppression of Vice," approached postal inspectors with his suspicion that a particular doctor was violating the law. ${ }^{177}$ The postal employees eagerly approved of the agent's plan and the agent proceeded to compose a letter to his suspect requesting information about contraception. ${ }^{178}$ He signed his request with a made-up name, Miss Nettie G. Harlan of Butler, Georgia, and put it in the mail. When the doctor responded with only thinly veiled illicit information, the postal employees pulled his letter from the mail and gave it to the agent. ${ }^{179}$ Relying, in part, on the consent doctrine drawn from the state burglary cases, the court, in United States $v$. Whittier, ${ }^{180}$ reasoned that even though the defendant is "as morally guilty as if the letter he was answering had been written by a person seeking the prohibited information, and not by a detective," the situation lies outside the particular language of the statute. ${ }^{181}$ In other words, because the defendant's letter was written and addressed to a fictitious person, there is no way that it could have given "the prohibited information" to anyone, as required by law. ${ }^{1.2}$ Patterned once again on private law, on crime with a perpetrator and a victim, the court developed the first federal precursor to

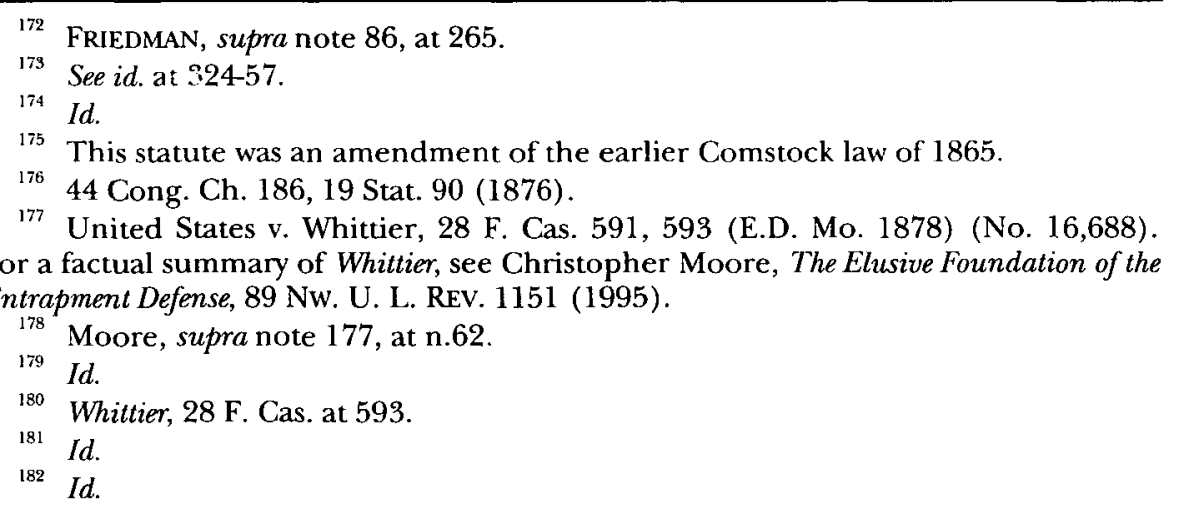


entrapment law. Applying an extremely formal interpretation of the statute, a method in vogue at that time, the court dismissed the indictment. $^{189}$

This doctrine concerning decoys and mail fraud persisted for decades. Like the analogous state court doctrine of consent, however, it evolved and changed. In the $1880 \mathrm{~s}$ and $90 \mathrm{~s}$, courts stretched the private law concepts to their extreme. ${ }^{184} \mathrm{~A}$ federal court in Illinois argued that contributory negligence on the part of the government could not constitute a defense unless the government somehow broke the causal relationship between the offender and the offense. ${ }^{185}$ Courts simply did not have the language to explain the concept. They grasped at familiar doctrine for help, but the causal relationship between offender and offense proved an odd and awkward way of explaining voluntariness. ${ }^{186}$ Feeling the limits of private law concepts, courts picked up on the tone of the concurring opinion in Whittier. Writing separately, Judge Treat focused less on the letter of the law or the fictitious nature of the "victim," and insisted that what was really appalling was the government's effort to "induce or manufacture crime." 187 Faced with the same or similar statutes, courts further developed that rationale, arguing that the defendants were not guilty and convictions could not stand where government officials procured the crime ${ }^{188}$ Following Whittier, one court rejected an entrapment defense to the aforementioned statute, arguing that law enforcement traps warrant reversal "when the defendant was the passive tool of the entrapping party." ${ }^{189}$ The issue of decoys used to catch violations of various rules involving the mail reached the United States Supreme Court on several different occasions in the mid-1890s. In United States $v$. Grimm, ${ }^{190}$ the first such case, Justice Brewer wasted little time in concluding that there is no defense where the postal inspector did not intend "to induce or solicit the commission of a crime." The Court relied on Grimm to dismiss two other pleas for relief under the aforementioned statute. ${ }^{191}$

\footnotetext{
${ }^{183}$ Id. at 594. For a discussion of late-nineteenth century jurisprudence, see HORWITZ, supra note 8, at 9-30.

${ }^{184}$ Most courts used a modified version of the consent doctrine regardless of whether they upheld or reversed the conviction. See, e.g., United States v. Duff, 6 F. 45 (C.C.S.D.N.Y. 1881 ).

${ }_{185}$ Bates v. United States, 10 F. 92,99 (C.C. Ill. 1881).

${ }^{186}$ Id

187 Whittier, 28 F. Cas. at 594 (Treat, J., concurring).

188 E.g., United States v. Adams, 59 F. 674, 677 (D. Or. 1894).

189 Bates, 10 F. at 92.

190156 U.S. 604,610 (1895).

${ }^{191}$ See United States v. Andrews, 162 U.S. 420, 424 (1896); see also Price v. United
} 
The first entrapment case, outside of the mail fraud decoy context, reached the federal courts in $1915 .{ }^{192}$ Seven years earlier, California immigration agents suspected that Woo Wai, a ChineseAmerican merchant, had information about a smuggling ring, which was so pervasive that it involved various high-level government officials. ${ }^{193}$ Hoping to arrest Woo Wai for violating the immigration laws and get him "in the door" so he would provide information on the other suspects, the government agents sought to involve him in an elaborate plan to smuggle illegal Chinese aliens from Mexico. ${ }^{194}$ Woo Wai refused to participate on several occasions. ${ }^{195}$ Undaunted, officials used government funds to hire a detective who brought Woo Wai from San Francisco to San Diego on two separate occasions in order to entice him to join the operation. ${ }^{196}$ After two trips down the coast and extensive coaxing, Woo Wai finally acquiesced. ${ }^{197}$ Poised as Woo Wai crossed the border with the illegal aliens in tow, immigration agents arrested him and offered him immunity if he cooperated in uncovering the smuggling operation. ${ }^{198} \mathrm{He}$ refused, opting instead to go to trial on the charge that he conspired to bring illegal aliens across the border in violation of the immigration laws. ${ }^{199}$

At trial, Woo Wai argued that the government agents had unfairly lured him into the crime. ${ }^{200}$ The district court promptly issued an instruction denying the existence of any such defense. On appeal, the Ninth Circuit Court of Appeals reversed on two separate grounds. ${ }^{201}$ First, it drew on the state court consent doctrine to reason that because the government consented to the admission of the aliens, there was no offense. ${ }^{202}$ Second, the court offered its innovative spin: "sound public policy can be upheld only by denying the criminality of those who are thus induced to commit acts which infringe the letter of the criminal statutes." ${ }^{203}$ Distinguishing relevant

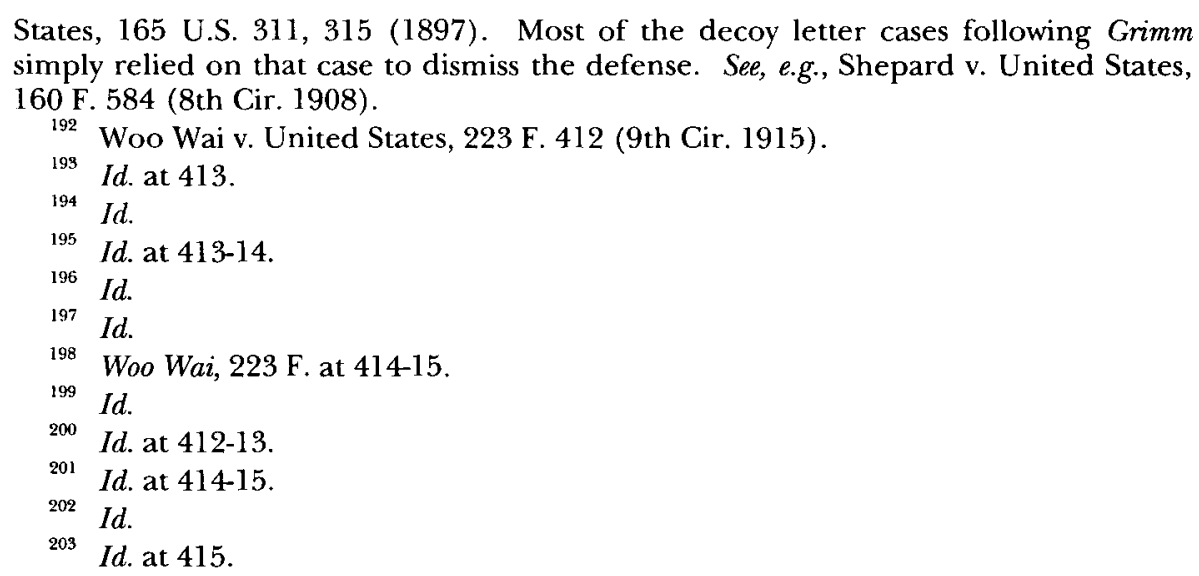


state law cases and echoing others, the court held that when the criminal intent does not originate in the mind of the defendant, he cannot be held responsible. ${ }^{204}$ Thus, the precedent was set. The court offered two rationales: the first, reminiscent of the older state cases, reasoned by analogy to private law doctrine; and, the second, insisted that an act simply was not "criminal" if the government itself manufactured the crime and manipulated the defendant into committing it. ${ }^{205}$

As the cases progressed into the twentieth century, the language of consent became more rare, muted by the more pervasive rationale that an individual defendant cannot act of his own free will if he was sufficiently manipulated by the government. A few years later, another case arose out of similar facts. ${ }^{206}$ The court concluded without much difficulty, " $[w]$ here the officers of the law have incited the party to commit the crime charged and lured him on to its consummation, the law will not authorize a verdict of guilty." ${ }^{207}$ Like the later state cases, the federal courts that acknowledged the entrapment defense in the $1910 \mathrm{~s}$ focused on the origin of the criminal intent. ${ }^{208}$

Courts disagreed on where to draw the line, and as Kenneth Murchison artfully argues, the outcome of their reasoning often reflected their own, and the public's, attitude to the law under which the defendant was indicted. ${ }^{209}$ The early state and federal entrapment cases, however, did not only involve violations of prohibition laws. Like Woo Wai and the state bribery cases, many were the result of the efforts of an overzealous reform movement, which had gradually made its way into various wings of law enforcement. What is striking about the cases that recognize the defense is not the particular statutes under which they arose, but rather the organized and sophisticated nature of the law enforcement offensive considered by the courts. Both federal and state courts had to reinvent the doctrine

204 Woo Wai, $223 \mathrm{~F}$, at 414.

${ }^{2015} \quad$ Id. at $414-16$.

206 Yick v. United States, 240 F. 60 (9th Cir. 1917).

207 Id. at 65

208 Peterson v. United States, 255 F. 433, 435 (9th Cir. 1919) (reversing a conviction for a wartime offense of selling liquor to soldiers in uniform after undercover agents harassed the defendant for over three hours in an effort to procure alcohol); Voves v. United States, 249 F. 191, 192 (7th Cir. 1918) (reversing a conviction for selling liquor to an Indian); United States v. Healy, 202 F. 349, 351 (D. Mont. 1913) (reversing a conviction under same law after federal officials hired an Indian witness, who did not look or seem like an Indian, to procure alcohol from the defendant).

${ }^{209}$ See MURCHISON, supra note 94, at 41-46. 
to suit this new situation. They discarded the terms of contract and other private law models and adopted a new theory of entrapment based on a new idea of what constitutes voluntary action in the presence of a large, centralized, and bureaucratic state.

The subtle shift in language may not have had a huge impact on who served time for which crime, but significantly, both defense lawyers and judges now framed their understanding of criminal responsibility in a new way. The idea that the government could "create" a criminal was a new concept. The twentieth-century legal doctrine of entrapment, which embodied the idea that the state wielded some kind of power to manipulate the very essence of its citizens, was an innovation in the law. The later state and federal entrapment cases made the implication of this new focus on criminal intent explicit, excusing a criminal defendant only when the state authorities created him. Thus, one state court admonished, "decoys and artifices may be employed to entrap criminals, but not to create them." ${ }^{210}$ Another rejected the defendant's claim that the state officials were engaged in a "conspiracy to create a criminal." 11 In a West Virginia court, the judge grasped at various metaphors to explain the law, stating, there can be no entrapment unless "the defendant was plastic clay in the hands of the entrappers. ... It is not the decoy of a criminal which public policy condemns but the implanting of the germ of criminality, no matter how favorable the culture." $" 212$

Federal courts used the same language to express alarm at the government's ability to distort the will of its citizens. In an attempt to catch a suspect violating an act that prohibed the sale of liquor to Indians, federal officials hired a witness who did not appear to be an Indian. ${ }^{213}$ The court declared, "[d] ecoys are permissible to entrap criminals, but not to create them, to present opportunity to those having intent to or willing to commit crime but not to ensnare the law-abiding in unconscious offending." ${ }^{214}$ The court reasoned that the combination between ignorance of fact and government solicitation "stamps the act as involuntary" because the defendant had become a merely passive instrument of governmental design. ${ }^{215}$ The

${ }^{210}$ State v. Hester, 146 S.E. 116, 120 (S.C. 1929). For parallel language, see People v. Schell, 240 Ill. App. 254 (Ill. App. Ct. 1926); Commonwealth v. Wasson, 42 Pa. Super. 38 (Pa. Super. Ct. 1910).

${ }^{211}$ State v. Lovell, 272 P. 666 (Kan. 1928).

${ }^{212}$ State v. Jarvis, 143 S.E. 235, 236 (W. Va. 1928).

${ }^{213}$ Healy, $202 \mathrm{~F}$. at 349.

214 Id. at 350 .

215 Id. 
Ninth Circuit echoed this idea of free will noting that, "[t]he government is not engaged in the business of manufacturing criminals." ${ }^{216}$ The federal cases that followed in the 1920s similarly focused the inquiry on the power of the state, through sheer force of persuasion, to change the course of human conduct and eradicate individual free will. ${ }^{217}$

While the shift was subtle, it is nonetheless evident. The earlier cases defined will, freedom, and voluntariness by reference to actions. If a defendant committed an illegal act without physical coercion in the nineteenth-century cases, he did so of his free will. The consent doctrine, for instance focused on the victim's acquiescence in the crime, not on the defendant's free will, because the voluntariness of the defendant's actions was presupposed. This mirrors the biblical interaction of Eve and the serpent. The reason God did not excuse Eve is that she acted against his edict, and was therefore culpable. The serpent wielded a good deal more power than Eve and his tactics were certainly unfair, but in the mind of the Old Testament Deity and the New York court which invoked Him, that was not really relevant. By the twentieth century, courts had taken a noticeable turn. In response to a new kind of state with an intricate network of national, local, and private law enforcement tools at its fingertips, courts generated and adopted the following new concepts: (1) that an individual's will can be undermined; (2) that an individual's personality can evolve and change; and (3) that an individual free from coercion is not necessarily free. Under this rubric, an individual is not responsible for his acts if the state manipulated his will..

The older idea of character based on a Judeo-Christian conception of the fixed and unchanging self, with virtues and vices that can be more or less controlled by the individual, dominated earlier case law. ${ }^{218}$ One appellate court made it clear that this version

\footnotetext{
216 Peterson, 255 F. at 436.

${ }^{217}$ See, e.g., Conway v. United States, 1 F.2d 274, 276 (7th Cir. 1924); Sabbatino v. United States, 298 F. 409, 411 (2d Cir. 1924); Ritter v. United States, 293 F. 187, 18889 (9th Cir. 1923); Browne v. United States, 290 F. 870, 873-74 (6th Cir. 1923); DiSalvo v. United States, 2 F.2d 222, 225-26 (8th Cir. 1924).

${ }_{218}$ For a broad theoretical discussion of the crisis of the individual in the late nineteenth century, see Thomas C. Heller \& David E. Wellbery, Introduction to RECONSTRUCTING INDIVIDUALISM: AUTONOMY, INDNIDUALITY, AND THE SELF IN WESTERN THOught 7-15 (Thomas C. Heller et al. eds., 1986). The shift from the religious to the secular in the law occurred throughout the nineteenth century, but it was especially significant after the Civil War. Thus, this shift in notions of the self was just one aspect of a much broader trend away from religious conceptions of the self. See generally Ross, supra note 56, at 53-64; ABRAMS, supra note 154.
} 
no longer suited the modern world. ${ }^{219}$ The trial court invoked Jesus in its jury charge stating, "on the night before the crucifixion, Jesus tempted Judas Iscariot: that he could have remained away and saved Judas Iscariot from committing the despicable crime . . . of betraying his master." It may be argued, the court continued, that Jesus tempted Judas, but that provided no excuse because "it was in the heart of this man." 220 On appeal, the court concluded that it was an error to rule out the entrapment defense altogether and noted that the instruction was unduly prejudicial. ${ }^{221}$ The emergence of the defense based on the vulnerability of individuals and the elusiveness of free will embodied a definition of freedom and individuality that directly contradicted older biblical notions.

As the doctrine developed across the continent, federal courts gradually proved more liberal in ordering lower courts to consider all the evidence related to the entrapment defense. ${ }^{222}$ Kenneth Murchison argues that it was prohibition that prompted courts to open their doors to the new defense. ${ }^{223}$ While the widely controversial prohibition laws might have served as a catalyst, the array of cases in the early part of the twenty-first century set the stage. The language of the defense was already well established in both the federal and state courts by the time the prohibition cases flooded the courts. Prohibition may have brought entrapment to the attention of the federal judiciary in a way that it found hard to ignore but the defense had already developed over the course of many decades as a collective response to a radically changed universe of law enforcement.

Meanwhile, legal commentators were largely unmoved by the judicial development of the entrapment defense. Nineteenth-century treatises rarely mentioned the subject and if they did, they did so by explaining the doctrine of consent. ${ }^{24}$ In his treatise on criminal law

\footnotetext{
219 Di Salvo, 2 F.2d at 226.

220 Id.

221 Id.

222 See MurChison, supra note 94, at 29-32.

${ }^{223} I d$.

224 Most treatises did not devote any space to entrapment. See, e.g., Francis Wharton, a Treatise on Criminal LAW (1896); JOHN Minor, ExPOSITION OF THE LAW of Crime and Punishment (1894); John Wilder May, LaW of Crimes (1893); J.H. Beale, A Selection of Cases (1894); Irving Browne, The Elements of Criminal law, Principles, Pleading, and Procedures, For the USE of LaW Schools and Students (1892); S.F. HaRris, Principles of Criminal LAW (1883); Joel Prentiss BISHOP, COMMENTARIES (1882). The few that did mention it did so in passing and largely focused on the consent cases. See, e.g., JOHN G. WHALEY, THE CRIMINAL LAW 3739 (1896); William Clark, Selected CaSES ON CRiminal LAW (1895).
} 
published in 1895, for instance, William Clark coupled the fact that consent to sexual intercourse negates an element of rape with the notion that a cooperating witness's consent negates an element of larceny or robbery. ${ }^{225}$ In the early decades of the twentieth century, the defense drew few comments from students cataloguing cases and even fewer scholarly studies. ${ }^{226}$ In the second half of the prohibition decade, however, academics took a greater interest in entrapment and, like the courts, they seemed to embrace the defense as if it had always been around. ${ }^{227}$ These later comments, like the court cases they discussed, generally noted that entrapment serves as a successful defense where the criminal intent originates with the government agents rather than the accused. ${ }^{228}$ As one commentator put it in the late 1920s, courts apply the defense when "acts of the officers instigating and procuring the crime have gone so far as to wash the necessary guilty intent from the mind of the accused and render him a mere tool with no intent. ${ }^{, 299}$ Another commentator remarked that the origin of the criminal design is only the beginning of the inquiry; entrapment can only succeed as a defense if the government deprived the accused of "volition and willing compliance.,"230 Others put it slightly differently, arguing that if government officials produce a crime that the defendant would not otherwise have committed, the defendant can claim that he was unjustly entrapped. ${ }^{231}$ Treatises in

${ }^{225}$ ClaRK, supra note 224, at 23 .
The Index to Legal Periodicals did not include entrapment as a category until 1924, and only three articles appeared on the subject. See INDEX TO LEGAL PERIODICALS AND LAW LibraRY JOURNAL 81 (1924); see also Leonard J. Calhoun, When Entrapment is a Bar to Conviction, 10 VA. L. REV. 316 (1924); Criminal Law-Entrapment to Sell Liquor, 33 YALE L.J. 555 (1924); Entrapping Suspected Criminals, 28 CASE \& COMment 263 (1922). See also MURChison, supra note 94, at 26.

${ }_{227}$ E.g. J. Darwin Bond, Entrapment in Narcotic Law Violations, 20 KY. L.J. 98 (1931).

${ }_{228}$ See, e.g., Robert C. Kline, Entrapment Under the National Prohibition Act, 1 GEO. WASH. L. REv. 371,372 (1932); Recent Case Notes, Criminal Law-Entrapment as a Defense in Criminal Prosecutions, 1 IDAHO L.J. 93, 93 (1931); Bond, supra note 227, at 99; Recent Decisions, Criminal Law-Trial-Entrapment as a Defense Where Criminal Intent Originates in Accused, 16 VA. L. REv. 78, 78-79 (1929); Comment, Criminal LawDefenses-Entrapment, 2 S. CAL. L. REV. 283, 286 (1928).

${ }_{229}$ Criminal Law-Defenses-Entrapment, supra note 228, at 286.

${ }^{230}$ Recent Decisions, Criminal Law-Entrapment, 13 ST. LOUIS U. L. REv. 275, 27576 (1928); see also Note, Entrapment as a Defense to Criminal Prosecution, 44 HARV. L. REv. 109, 109 (1930) (noting that entrapment is reprehensible because "it involves the creation of a criminal by a governmental agency").

${ }^{231}$ E.g., Recent Cases, Criminal Law-Defenses-Entrapment, 20 ILL. L. REv. 309, 309 (1925); Recent Decisions, Criminal Law-Entrapment, supra note 231, at 275-76; Recent Cases, Criminal Law-Entrapment-Public Policy, 9 TEX. L. REv. 276, 277-78 (1930); Note, Entrapment as a Defense in Prosecution for Prohibition Violation, 41 YAle L.J. 1249, 1249-51 (1932); Recent Cases, Criminal Law-Entrapment as a Defense, 11 TEX. L. REV. 385, 385 (1932). 
the second half of the century echoed this sentiment. ${ }^{232}$

While prohibition did not create the entrapment defense, the growing skepticism about liquor laws prompted both courts and commentators to adopt a new rationale for the defense. At the end of the decade, scholars argued that the entrapment defense was worthwhile because it served to deter the overly aggressive and invasive behavior of law enforcement officials. They argued that whether or not the government agents had reasonable suspicion and acted in good faith prior to setting their trap provides a doctrinal check on executive power. ${ }^{233}$ This reasoning is notably absent from the earlier judicial decisions implementing the defense, but it did make a subtle appearance in a few cases in the mid-twenties. ${ }^{234}$ In these cases, courts never explicitly invoked deterrence as the purpose of entrapment, rather, courts suggested that if the government agents implemented a trap without reasonable suspicion, they acted contrary to public policy, which counsels against inducing individuals to commit crimes, and dictates that courts should not countenance such conduct. ${ }^{235}$

While the lower courts and academics struggled to define the contours of the entrapment defense, the Supreme Court remained silent. ${ }^{236}$ It was not until 1928 that the Court acknowledged this new defense in federal criminal law. The case which first made its way to the United States Supreme Court was a narcotics case: Federal agents suspected that Casey, an attorney, was soaking towels with illegal opiates and delivering them to federal prisoners at a county jail. ${ }^{237}$ Federal narcotics agents recruited George Cicero, a convicted felon and drug addict, and Mrs. Nelson, another prisoner's sister-in-law, to serve as their stool pigeons. ${ }^{238}$ The agents installed a dictaphone in

${ }^{232}$ Clark \& MARShall, LAW OF CRIMES $\$ 162$ (3d ed. 1927).

${ }^{233}$ See, e.g., Bond, supra note 227, at 99; Fred J. Ginsburg, Criminal Cases, Entrapment-Narcotic Sale in Violation of Harrison Narcotic Act, 24 J. CRIM. L. 1109, 1109 10 (1933); Criminal Law-Defenses-Entrapment, supra note 228, at 286-89. One author claimed that although courts frame their inquiry in terms of the origin of criminal intent. they are in fact simply calculating whether the government conduct was objectively reasonable. Note, Entrapment by Government Officials, 28 CoLuM. L. REv. 1067, 1069 (1928).

${ }^{234}$ United States v. Eman Drug Mfg. Co., 271 F. 353 (D. Colo. 1920); see also United States v. Certain Quantities of Intoxicating Liquors, 290 F. 824 (D.N.H. 1923).

${ }^{235}$ See, e.g., De Long v. United States, 4 F.2d 244 (8th Cir. 1925); Certain Quantities of Intoxicating Liquors, 290 F. 824.

${ }^{236}$ MURCHISON, supra note 94, at 32. Murchison points out that, between the years of 1919 and 1932, the Court declined to grant certiorarion the issue twelve times. Id.

${ }^{237}$ Casey v. United States, 276 U.S. 413, 416-17 (1928).

${ }_{238}$ Id. at 422 (Brandeis, J., dissenting). 
the attorney-client cage and deposited money in Cicero's prison credit account. ${ }^{239}$ They listened from an adjacent room while both Cicero and Nelson solicited drugs from Casey. ${ }^{240}$ Without much comment, Justice Holmes rejected Casey's plea that he had been trapped into committing the crime. ${ }^{241}$ Justice Brandeis dissented. ${ }^{242}$ He remarked that he could not consider the substantive offense because "officers of the government instigated the commission of the alleged crime." ${ }^{243}$ Justice Brandeis clarified that his objection does not rest merely upon the character of the evidence or upon the fact that the evidence was illegally obtained. ${ }^{244}$ The obstacle to the prosecution lies in the fact that the alleged crime was instigated by officers of the government; that the act for which the government seeks to punish the defendant is the fruit of their criminal conspiracy to induce its commission. ${ }^{245}$

Further, the Justice insisted that the government could set decoys and lay traps, "[b]ut it may not provoke or create a crime and then punish the criminal, its creature." ${ }^{246}$ Categorizing Casey as a "detective-made criminal," Brandeis offered two reasons for his dissent, arguing that the court could not sanction the government's unauthorized and unjustifiable conduct and that Casey's action could not be considered an act of his own free will. ${ }^{247}$

Four years later, the majority of the Court adopted Brandeis's reasoning. In United States $v$. Sorrells, the defendant was convicted of violating the National Prohibition Act. ${ }^{248}$ At trial, he relied on an entrapment defense, claiming that government agents staged a crime and lured him into committing it. ${ }^{249}$ In an elaborate effort to catch Sorrels in an illicit act, a government agent posed as a tourist and recruited Sorrells's friends to introduce him. ${ }^{250}$ After using various intelligence sources, he found out that Sorrells had fought in World War $I^{251}$ The agent then pretended to be a veteran of the same

\footnotetext{
Id. (Brandeis, J., dissenting).

Id. at 422-23 (Brandeis, J., dissenting).

Id. at 418-19.

$I d$. at 421 (Brandeis, J., dissenting).

Casey, 276 U.S. at 421 (Brandeis, J., dissenting)

${ }^{244}$ Id. at 423 (Brandeis, J., dissenting).

${ }^{245}$ Id. (Brandeis, J., dissenting)

${ }^{246}$ Id. (Brandeis, J., dissenting)

${ }^{247}$ Casey, 276 U.S. at 423-24 (Brandeis, J., dissenting).

${ }^{248}$ United States v. Sorrells, 287 U.S. 435, 438 (1932).

${ }^{249} I d$. at $438-40$.

250 Id. at 439.

${ }^{251}$ Id.
} 
Division. After winning his confidence in this cunning way, the agent asked for liquor on three separate occasions. ${ }^{252}$ Sorrells finally gave in. ${ }^{253}$ The Court noted that:

the evidence was sufficient to warrant a finding that the act for which defendant was prosecuted was instigated by the prohibition agent, that it was the creature of his purpose, that defendant had no previous disposition to commit it ... and that the agent lured defendant, otherwise innocent, to its commission by repeated and persistent solicitation in which he succeeded by taking advantage of the sentiment aroused by reminiscences of their experiences as companions in arms in the World War. ${ }^{254}$

Chief Justice Hughes paused, "[s]uch a gross abuse of authority given for the purpose of detecting and punishing crime, and not for the making of criminals, deserves the severest condemnation." Following the vast majority of circuits, the Court held that when the criminal design originates with the government, it may not prosecute the individual who it caught and enticed into its plan. ${ }^{256}$

While the Supreme Court might have used substantive due process to build the defense permanently into the law, the Court chose not to do so. Instead, the justices insisted that Congress could not possibly have intended its statute to cover a situation like thiswhere government agents lured an innocent person into committing a crime. ${ }^{257}$ Thus, the defense, which just decades before occupied a small and precarious position in both state and federal courts, had evolved into such a commonsense guage of criminal responsibility that the Supreme Court was willing to conclude it would be absurd for Congress to have intended any criminal statute to include prosecution and punishment of those enticed and trapped by government agents. ${ }^{258}$ In Sorrells, the government argued that the defendant waived the entrapment defense by not mentioning it in his plea of not guilty and failing to plead it to bar further proceedings

52 Id.

253 Sorrells, 287 U.S. at 439.

${ }^{254}$ Id. at 441.

${ }^{255} I d$

${ }^{256}$ Id. By the time the Court reviewed the issue in Sorrells, entrapment was not a controversial doctrine and only one justice agreed with the circuit court that no such defense exists. Id. at 453 (McReynolds, J., dissenting).

${ }^{257}$ See id. at 448-49. While few contemporary discussions of entrapment explore the history in full, they all involve some discussion of Sorrells. For a thorough examination of the opinion, see Roger Park, The Entrapment Controversy, 60 MinN. L. REV. 163, 164 (1976).

${ }^{258}$ See Sorrells, 287 U.S. at 453. 
under the indictment. ${ }^{259}$ The Court rejected this contention, arguing that it follows from the misconception that the defense is not a denial of guilt but rather some sort of judicial bar or equitable doctrine that prevents the government from proceeding when its agents have behaved unjustly. ${ }^{260}$ Entrapment, the Sorrells Court explained, "is available, not in the view that the accused though guilty may go free," but rather pertains directly to the guilt or innocence of the defendant. ${ }^{261}$ It is significant that the Court chose not to use substantive due process, a doctrine employed throughout the previous decades, to defeat reform legislation and protect freedom of contract. Perhaps perceiving the already precarious position of substantive due process, the Court chose a different track, elevating this new aspect of freedom above such contractual rights.

Justice Roberts wrote separately to emphasize a slightly different basis for his adoption of entrapment. Rather than locate the source of the defense in Congressional intent, Justice Roberts chose to focus on the inherent supervisory power of the courts. His opinion echoed the flurry of academic articles published at the end of the previous decade and a few recent federal cases. The Justice stated that, "[n] either courts of equity nor those administering legal remedies tolerate the use of their process to consummate a wrong. The doctrine of entrapment in criminal law is the analogue of the same rule applied in civil proceedings." ${ }^{262}$ Justice Roberts argued that, while cloaked as an effort to tailor the law to a new view of criminal responsibility, entrapment was really a deterrent. Judges considered entrapment a judicial rule analogous to the various civil law doctrines that prevent plaintiffs from resorting to the courts when they have behaved in an illegal or grossly unethical manner. ${ }^{263}$

It may have been the waning popularity of prohibition that caused the Supreme Court to adopt the entrapment defense and articulate the new deterrent rationale, but the definition of criminal responsibility had already shifted. Courts had already redefined the relationship between the government and the individual. By insisting that no federal criminal statute could possibly imply otherwise, the Supreme Court crystallized the relationship and implanted itself in the role of patrolling this new boundary between state and citizen,

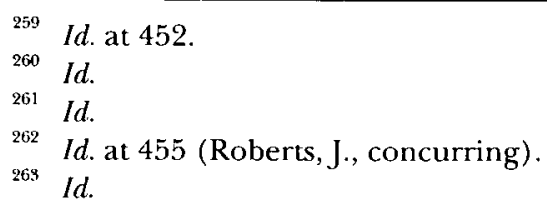


government official and civilian..$^{264}$

Thus, as the scope and reach of both state and federal criminal law grew at the end of the century, law enforcement grew with it. Judges and courts, largely without assistance from the academy, invented the doctrine of entrapment to accommodate this new amorphous form of government. ${ }^{25}$ By shifting away from private law notions of contract, courts slowly redefined criminal responsibility and realigned the precarious balance between government and the citizen. With little fanfare, courts and legal doctrine contributed to a new definition of free will, one which comprehended the power of the state-through manipulation, trickery, and deception-to alter personality and change the course of human conduct in some fatal way. The dominant justification for entrapment finally articulated by the Supreme Court in Sorrells centered on a definition of freedom and responsibility that had evolved over the past several decades. ${ }^{266}$ Some of the later federal cases, many law review commentaries in the later part of the 1920s, and the dissent in Sorrells suggest a related but distinct rationale: that entrapment is necessary for the purity of the government and its various agencies and agents, and the defense somehow deters government abuses of power and should be allowed despite the indisputable guilt of the accused. This sort of reasoning emerged only after most federal and state courts had adopted the defense. It served only a recessive role-while popular with academics, it did not dominate the early court cases on entrapment.

\section{ENTRAPMENT LAW IN CONTEXT}

This history of the entrapment defense, discussed in the preceding section, has spawned two warring tests to evaluate whether a defendant was impermissibly entrapped. ${ }^{267}$ The first of these tests, the subjective test, asks whether the defendant was predisposed to commit the crime before encouraged to do so by a government actor. ${ }^{268}$ The second test, the objective test, exonerates the defendant if government conduct exceeded acceptable limits. ${ }^{269}$ The subjective test, espoused by the majority of the Sorrells Court, dominated judicial decisions from the beginning of the defense's history. ${ }^{270}$ This test

\footnotetext{
${ }^{264}$ Id. at 452; see also id. at 457 (Roberts, J., concurring).

265 See, e.g., Sorells, 287 U.S. 435.

266 Id. at 451-52.

267 Paul Marcus, The ENTRAPMENT DeFENSE 12 (1995).

${ }^{268} I d$. at 53.

269 Id. at 169.

${ }^{270}$ Almost all federal courts employ the subjective test. A few state courts have embraced the objective test, but, like the federal clerkship, most also adhere to some
} 
makes sense if we view entrapment as a way of approximating whether the defendant acted of his own free will, rendering him guilty and responsible under the law. The objective test follows logically from later rationale, articulated most succinctly by Justice Roberts in his Sorrells concurrence, that courts should not sanction this sort of abuse of governmental authority. ${ }^{271}$

The history of law enforcement and entrapment is useful because it illustrates that the defense emerged primarily as a way of redefining criminal responsibility and autonomy after the Civil War. Most courts in the first few decades of the defense reasoned that the accused simply was not guilty if government officials manufactured the crime and molded the criminal. Judges did not use the defense primarily to deter, or even to send a message condemning governmental misconduct until well into the twentieth century. This chronology is relevant because it helps explain why courts have clung rather stubbornly to the subjective test in analyzing entrapment. The two rationales are related in that they both call for a particular boundary between the individual and the state, but the objective test follows logically only if the primary role of the defense is to deter governmental misconduct and preserve the purity of the courts. ${ }^{272}$ The subjective test embodies the slightly different earlier concern about what exactly constitutes criminal responsibility: A person cannot be considered responsible if he did not act of his own free will, especially when the government has the power to undermine free will through its control over resources and information, and through its power of persuasion.

Following the lead of early academic reflections on entrapment, most contemporary commentators suggest that courts abandon the impractical, and arguably even futile, subjective test. ${ }^{273}$ While attempting to ascertain the criminal predisposition of the accused is a clumsy and imprecise tool, the history of the defense indicates that we should allow courts to try. This particular inquiry enables courts to draw, erase, and redraw the line between government and citizen, a judicial role which has come to make sense to us. Thus, the frustrating task of locating the origin of criminal intent serves an important role in providing doctrinal room to shape an evolving notion of the proper interaction between the state and the individual, and in securing the position of the courts to police the parameters of

\footnotetext{
formulation of the subjective test. See MARCus, supra note 267, at 38 .

${ }^{271}$ Sorrells, 287 U.S. at 454-55 (Roberts, J., concurring).

272 MARCus, supra note 267, at 171-73.

273 See infra note 277.
} 
that precarious relationship. ${ }^{274}$

For example, sparked in part by the controversy over the role of the independent counsel in uncovering incriminating evidence about former President Bill Clinton ${ }^{275}$ and the debate over law enforcement and the Internet, ${ }^{276}$ recent literature on the entrapment defense almost universally condemns the subjective test. ${ }^{277}$ But, courts do not appear to comply with the cries of the academy. While the theoretical critique of the subjective test is perfectly logical, the subjective formulation perseveres for precisely the same reason that entrapment emerged in the first place; it allows the law to articulate and develop its own version of what it means to act freely in the modern world. By recognizing some elusive moment when the state has managed to manipulate its citizens and undermine free will through sheer force of persuasion, courts generate an evolving definition of freedom and individuality.

In his seminal article, Michael Seidman argues that because there is no such thing as predisposition, the two tests collapse. ${ }^{278} \mathrm{He}$ reasons that as long as one equates predisposition with readiness to commit a crime, courts can only guess at its existence by positing some level of inducement to which even an innocent, or nonpredisposed person, would respond. ${ }^{279}$ Thus, in order to distinguish the defendant who is worthy of exoneration from the one who is not, courts will have to analyze the propriety of government conduct-the very factor that the subjective test pretends to ignore. ${ }^{280}$ The problem with this theory, as Ronald Allen points out, is that it assumes what it is trying to prove-that the only way to evaluate an individual's state of mind is by reference to an objective test. ${ }^{281}$ Other forms of

${ }^{274}$ My argument here is consistent with Lawrence Lessig's theory of "fidelity in translation." See Lawrence Lessig, Understaning Changed Readings: Fidelity and Theory, 47 STAN. L. REV. 395 (1995). For another account of the dynamic nature of the common law, see Michael C. Dorf, Forward, The Limits of Socratic Deliberation, 112 HARV. L. REV. 4, 7 (1998).

${ }^{275}$ James F. Ponsoldt \& Stephen Marsh, Entrapment When the Spoken Word is the Crime, 68 FORDHAM L. REV. 1199, $1199-1200$ (2000).

${ }^{276}$ E.g., Katyal, supra note 5.

${ }^{277}$ E.g., Ronald J. Allen et al., Clarifying Entrapment, 89 J. CRIM. L. \& CRIMINOLOGY 407, 410-11 (1999); Paul Marcus, Presenting, Back from the Almost Dead, The Entrapment Defense, 47 FLA. L. REv. 205, $225-27$ (1995); Louis Michael Seidman, The Supreme Court, Entrapment, and our Criminal Justice Dilemma, 1981 SUP. CT. REv. 111, 118-19 (1981). For one notable exception, see Ponsoldt \& Marsh, supra note 275, at 1229. 30 .

${ }^{278}$ Seidman, supra note 277 , at 119-20.

279 Id. at $118-19$.

$280 I d$.

281 Allen et al., supra note 277, at 410-11. 
evidence such as character witnesses and the defendant's own statements, though certainly difficult to evaluate, may be relevant. ${ }^{282}$

Even so, Seidman continues, police officers generally direct their efforts toward those who are predisposed to commit a crime. ${ }^{283}$ The two tests would reach different results only in the rare instance where the police reasonably but incorrectly assume that a given suspect is predisposed. ${ }^{284}$ Allen criticizes this conclusion, arguing that the objective test questions the propriety of the police officers' conduct not the target of their inducement. ${ }^{285} \mathrm{He}$ clarifies that the two tests collapse because the factfinder has no direct access to a defendant's state of mind. ${ }^{286}$ The only way to determine predisposition is by approximating how a reasonable person would behave. ${ }^{287}$ While Seidman's argument, coupled with Allen's amendment, makes sense, it too rests on the premise that because judges and juries cannot possibly get inside the defendant's mind, they ought not try. ${ }^{288}$

Additionally, Allen more convincing argues that predisposition is a fictional entity, a concept that cannot really exist. ${ }^{289}$ If you assume that almost everyone would commit a crime if provoked or enticed in some extreme way, then predisposition by itself cannot distinguish between those entitled to the entrapment defense and those who are not. ${ }^{290}$ He notes,

[ $\mathrm{t}$ ] he real point is that talk of "predisposition" is meaningless and commits an existential fallacy. A person who takes the bait has had his price met; a person who does not, has not. But, the person who does not take the bait almost always surely would take a higher, even if greatly higher, bait. The failure to take this one is evidence of his price, but not of predisposition. ${ }^{291}$

Allen goes on to argue that while this "silly" idea of predisposition fails to distinguish between defendants, whether or

${ }^{282} I d$. The propriety of government conduct is only a threshold issue in the subjective test, because no matter how egregious the agents' conduct a predisposed defendant would not be acquitted. See United States v. Russell, 411 U.S. 423, 440 (1973) (Stewart, J., dissenting).

${ }^{283}$ Seidman, supra note 277 , at 119-20.

284 Id.

285 Allen et al., supra note 277, at 411-12.

286 Id. at 412 .

$287 \mathrm{Id}$.

${ }^{288}$ Seidman, supra note 277 , at $126-27$.

${ }_{289}$ Allen et al., supra note 277 , at 413 .

${ }^{290}$ Id

${ }^{291}$ Id. 
not they responded to "market level inducements" does. ${ }^{292}$ He insists that we should exonerate only those individuals who responded to inducements that exceed real world market rates. ${ }^{293}$ He envisions both a financial and emotional market. ${ }^{294}$ Punishing someone who responds to extra-market inducement could not possibly further the goals of criminal law-to deter, to incapacitate, and to rehabilitatewhile prosecuting a defendant for responding to market level inducements would. ${ }^{295}$ Responding to an anticipated adversary, Allen argues that it may be difficult to ascertain the market price of inducements but it could not possibly be as futile as the subjective test, which requires "literally proof of the nonexistent.",296

Allen scoffs at the courts' efforts to curb the government's power to "create criminals." 2977 A modern-day Jerome Frank, Allen seems to want to purge the law of all its subjective musings. Attempting to determine a precise market level for the kind of emotional manipulation involved in sting operations, however, strikes this writer as equally absurd. He proposes that we estimate this market value by calling in experts. ${ }^{298}$ He suggests that rather than use the fuzzy evidence to show the defendant's subjective state of mind, courts can use experts to determine the market price for emotional manipulation to commit a crime. ${ }^{299}$ Relying on expert evidence and social science in this way ignores the fact that in its unscientific way, the common law generates its own evolving definition of the self, of individuality, and responsibility. While at times, resorting to the social sciences may be appropriate, it cannot always provide the answer to shaky, indeterminate, and subjective doctrinal judgments. Any effort to determine a given defendant's predisposition, like many other concepts in the law, will involve the factfinder's generalizing from her own experience and from what she believes is the normal, average way to act. That this is the case does not necessarily mean courts should abandon efforts to approximate subjective intent. Language is imprecise. But a critique of the law based on this premise, taken to its extreme, threatens to undermine the entire endeavor. If courts defer questions of criminal responsibility and the definition of free will to the social sciences, they essentially abdicate a

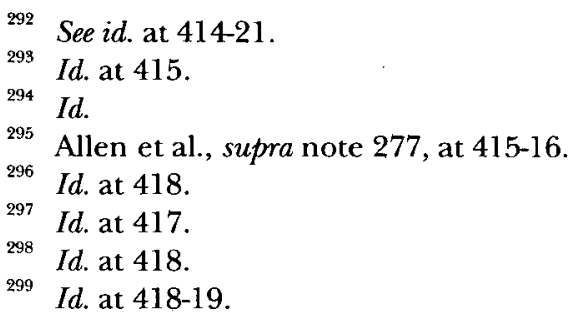


valuable role in generating the meaning of those terms over time. ${ }^{300}$

Allen proceeds to argue that given his understanding of entrapment, courts should also apply the doctrine when it is a private individual rather than the state that employs "extra-market" inducements to lure someone into committing a crime. ${ }^{301}$ Courts throughout the century have rejected this notion and again, it simply defies commonsense. Entrapment is not a private law concept. To the contrary, it appeared when it did because private law models could not comprehend individual freedom with respect to the modern state. The government could no longer pretend to be a neutral arbiter between individuals, and entrapment served to redefine freedom and criminal responsibility in the face of this changed reality. As such, applying the defense to private actors would be a radical and unwarranted departure from the history of entrapment.

\section{CONCLUSION}

Entrapment emerged at the turn of the century as a new way of policing the boundary between the government and the individual. As law enforcement's control over information and intelligence magnified, courts acknowledged the defense. They did so because freedom no longer seemed natural or inevitable in light of the governments newfound power. While both the objective and subjective tests are sloppy, the idea of predisposition involved in the subjective test is the most reasonable way for courts to determine how much control the defendant had over his own actions and thus, whether he ought to be held responsible. This may require the fact finder to resort to his own experience writ large, to what sort of inducements seem unfair, and to some approximation of what kind of inducements would lead most normal people to commit crimes. Judges and juries do this anyway. While Allen and Seidman's analyses reveal the futility of searching for origins of subjective intent, their critiques echo those of the progressive legal thinkers a century ago. Law in the post-Realist world has in many ways conceded to those sorts of criticisms by focusing largely on objective tests. Entrapment resisted the general trend. In so doing, is one of the arenas of legal

300 My point here is consistent with, though slightly different from, that of Ponsoldt and Marsh who insist that criminal laws without a moral component are likely to fail. See Ponsoldt \& Marsh, supra note 275, at 1229-30. It is too general to assert that all criminal laws ought to be subjective or ought to have a moral component. The Fourth Amendment exclusionary rule, for instance, is a criminal law with virtually no moral aspect. U.S. CONST. amend IV.

so1 Allen et al., supra note 277 , at 415 . 
doctrine that has preserved a role for courts in redefining individuality and freedom in the face of the radically changed nature of both state and federal government. While it can be useful to expose myths in the law, it is not always necessary to discard them. Asking whether the government created the criminal and whether the accused was predisposed to commit the crime integrates into the law a general notion that the government's monopoly over intelligence and information can undermine free will, and that it is the court's role to preserve and protect it.

As Susanna Blumenthal argues in her article on the creative role of the American judiciary, "[a]lthough the American concept of the rule of law may entail the suppression of judicial subjectivity, it seems also to require an exponent in the form of the human judge." ${ }^{302}$ This irony is difficult for some commentators to comprehend. Thus, they seek to purge the doctrine of its subjective component. Entrapment's stubborn resistance to this trend, however, reflects an understandable need to believe in the rule of law, or more particularly the role of criminal law in punishing only those who are in some personal sense responsible for their actions. At once invoking and critiquing Jerome Frank, Blumenthal concludes, that the fact we continue to trust the "finite figure" of the judge "with a task of such magnitude suggests that he cannot simply be viewed as a romantic survival. He expresses what is perhaps a more fundamental and unyielding human impulse to see beyond ourselves." ${ }^{303}$ Similarly, the subjective test for entrapment is not just a remnant of a more innocent time. While it is true that judges and juries will inject the notion of predisposition with all sorts of their own perceptions, that fact alone does not necessarily counsel against the perpetuation of the concept. By withstanding the trend toward the objective, the history of entrapment illustrates that pockets of the law remain myths that we, as a community, need to believe in. The myth of predisposition, or the unattainable goal of figuring out when the government has created a criminal, is not silly at all. It may be impossible to ascertain with any precision, but it reflects a willingness and desire to believe that our laws are more than just social science applied mechanistically to human interaction. The subjective test in this particular area of the law preserves a certain distinct and useful role for the courts in defining freedom and autonomy. ${ }^{304}$ It is part of

\footnotetext{
${ }^{302}$ Blumenthal, supra note 160 , at 227-28.

${ }_{303}$ Id. at 228.

304 On the role of free will as myth in criminal law, see HERBERT PACKER, THE Limits Of THE CRIMINAL SANCTION (1969).
} 
an evolving understanding, created through time by judges and juries-of what it means to be a free individual in the midst of a growingly diffuse state.

Even if we accept that in some form the subjective test is here to stay, more recent analyses have struggled to make sense of the Supreme Court's definition of "predisposition." ${ }^{305}$ In Jacobson $v$. United States, ${ }^{306}$ the jury found the defendant guilty of violating a statutory prohibition against knowingly receiving child pornography in the mail. ${ }^{307}$ The jury rejected Jacobson's entrapment defense and the circuit court affirmed, finding that the government had proved beyond a reasonable doubt that he was predisposed to commit the crime. ${ }^{308}$ The Supreme Court disagreed, holding that Jacobson was entrapped as a matter of law. ${ }^{309}$ Seemingly adhering to the subjective test, the Court insisted that the predisposition analysis is distinct from the nature of the government's conduct. Accordingly, the Court focused on whether Jacobson was predisposed to violate the law before government officials intervened. ${ }^{310}$

Government agents got Jacobson's name from a list of people who had received magazines depicting nude teenage boys before Congress criminalized such conduct. After Congress passed the statute three months later, two separate government agencies coordinated a campaign to tempt the defendant into violating the law. ${ }^{311}$ After resisting various solicitations over the course of two years, Jacobson gave in and ordered a child-pornography magazine from a fictitious organization invented by the government. ${ }^{312}$ The Court admitted that Jacobson was predisposed to commit the crime immediately before he purchased the illicit material but noted that the critical inquiry was whether he was equally disposed before the

305 See, e.g., Ponsoldt \& Marsh, supra note 275, at 1210-11.

306 Jacobson, 503 U.S. 540 (1992).

307 See 18 U.S.C. $\$ 2252$ (a) (2) (A) (2003).

308 Jacobson, 503 U.S. at 542.

309 Id.

310 Id. at 553-54 ("[W] hen the Government's quest for convictions leads to the apprehension of an otherwise law-abiding citizen who, if left to his own devices likely would have never run afoul of the law.").

${ }^{311} I d$. at 543. Among other things, the government sent mailings from fictitious organizations that claimed to be fighting censorship. Others asked him questions about his sexuality as part of a questionnaire. The government even created a fake correspondence from an individual who claimed to share Jacobson's particular sexual perversions. Finally, Jacobson relented and ordered a magazine from one of the fake organizations. See id. at 544-47.

Id. at 547. 
government entangled itself in his life two years before. ${ }^{313}$ Ruling that a defendant must be predisposed prior to any government involvement, the Court found the pre-investigation evidence wanting. ${ }^{314}$

In the wake of this decision, circuit courts have disagreed over whether Jacobson redefined entrapment to include an objective test for predisposition. ${ }^{915}$ In United States v. Hollingsworth, ${ }^{316}$ an opinion authored by Judge Posner, the Seventh Circuit held that someone is predisposed to commit a crime if he would have committed it without government interference. ${ }^{317}$ Judge Posner argued that Jacobson put a new objective spin on the predisposition analysis, directing us to examine the defendant's objective circumstances to ascertain whether he would have refrained from committing a crime "but for" the government's meddling. ${ }^{318}$ In other words, if ample opportunity to commit the crime would have arisen anyway, then the fact that the government provided an additional incentive might not matter. The First Circuit disagreed. ${ }^{319}$ It held that someone is predisposed if he would have committed the crime given an "ordinary opportunity. ${ }^{, 320}$

In a recent analysis, James Ponsoldt and Stephen Marsh argue persuasively that the objective element in the Seventh Circuit test is simply unwarranted by Jacobson. ${ }^{321}$ Thus, they conclude that "nothing in the Court's opinion ... endorses the notion that a person willing but unlikely to commit a crime is the sort of 'law-abiding citizen' for whom an entrapment defense should be available." ${ }^{, 322}$ While the Court's recent entrapment case lends some support for paying increased attention to the nature of the government's offensive (an objective component), it is perfectly consistent with the early history of entrapment law because it focuses entirely on the defendant's state of mind. Any evidence of exactly what the government did is relevant

313 Id. at 549.

s14 Jacobson, 503 U.S. at 550-51.

315 Compare United States v. Knox, 112 F.3d 802, 808 (5th Cir. 1997), and United States v. Hollingsworth, 27 F.3d 1196, 1201 (7th Cir. 1994) (en banc), with United States v. Thickstun, 110 F.3d 1394, 1398 (9th Cir. 1997), and United States v. Gendron, 18 F.3d 955, 961 (1st Cir. 1994).

316 F.3d 1196 (7th Cir. 1994) (en banc).

317 Id. at 1200 .

318 Id. at 1200. Paul Marcus, one of the leading legal authorities on entrapment offered an interpretation of Jacobson similar to Posner's. See Marcus, supra note 277, at 225-27.

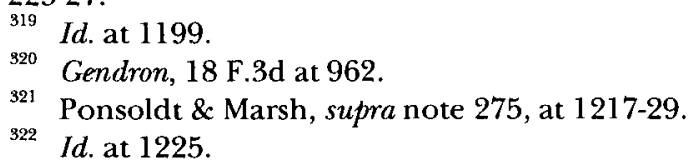


only insofar as it helps us approximate that subjective state.

The First Circuit proffers a test that provides a perfect balance. The test resembles a version of Allen's market analysis stripped of its sterile language. In United States $v$. Gendron, Judge Breyer ruled that if a defendant would have committed the crime given an "'ordinary opportunity," or an inducement that could not be categorized as improper, then he is predisposed. ${ }^{323}$ In thinking about predisposition, the jury and the judge will have no choice but to question what one would do if presented with an ordinary opportunity ${ }^{924}$ As Ponsoldt and Marsh put it,

[t]he Government's conduct has a bearing in assessing the probative value of the defendant's reluctance in relation to the Government's solicitation. In answering the ultimate question ... however, the court (or jury) will have to "assume away" the Government's conduct and ask how the defendant would have responded had that conduct not been present. ${ }^{395}$

By asking whether the defendant would have committed the crime given an ordinary opportunity, Gendron factors in the calculus of whether the government's conduct was particularly egregious. ${ }^{326}$ However, the primary purpose of the test remains to determine the defendant's subjective state of mind: Was he willing, rather than was he likely, to have committed the crime anyway?

Not surprisingly, Judge Posner cannot help but reveal an ulterior motive for his reading of Jacobson. ${ }^{327}$ In Hollingsworth, he remarks that the "but-for" causation test for predisposition produces the most socially productive result. ${ }^{328}$ Like Allen, Posner's economic analysis favors an objective test. Forced to work within the confines of stubborn Supreme Court precedent, he thinly disguises the wolf in sheep's clothing. As I argued above, the entrapment defense emerged not to supplement the growing reliance on social science and public policy but to resist the trend. Muddling over the subjective state of mind preserves a creative role for the judiciary in developing definitions of freedom and human responsibility. ${ }^{329}$ In

\footnotetext{
${ }^{323}$ Gendron, 18 F.3d at 961 . Judge Breyer recognized that in order to qualify as an improper inducement, the government would have to do something besides merely provide the opportunity to commit a crime. Thus, an "ordinary opportunity" means a government-sponsored opportunity without excessive additional pressure. Id.

324 Id. at 962.

${ }^{325}$ Ponsoldt \& Marsh, supra note 275, at 1231.

326 Gendron, 18 F.3d at 962.

327 Hollingsworth, 27 F.3d at 1199-1200.

328 Id. at 1203.

${ }^{329}$ See Blumenthal, supra note 160 , at $154-56$. It is not the purpose of this essay to provide a comprehensive critique of law and economics. On the other hand, I am
} 
order to continue to do so, it seems fair to recognize the difficulty of discerning a defendant's state of mind prior to the government's enforcement efforts, but it would be an error to transform the purpose of the defense by resorting to law and economics or policy decisions and replacing the subjective with an objective analysis.

The concept of entrapment emerged when it did because law enforcement outgrew its traditional status, and, perhaps, the defense needs to flex and change with a new breed of national intelligence, which has elaborate new tools at its fingertips. Efforts to trap individuals using modern technology like the Internet should force us to rethink entrapment and to redefine what constitutes predisposition, but it should not change the skeleton of the defense. Judge Posner quite artfully tries to do what Seidman considered inevitable. He wraps what is in essence an objective test in a subjective package. In the process he distorts United States Supreme Court precedent and betrays nearly a century of evolving doctrine. Judge Breyer, to the contrary, has intuited a better way to allow entrapment to evolve in response to the changing nature of law enforcement without altering the fundamental purpose of the defense. The goal of preserving doctrinal room for courts to define individuality and freedom may seem antiquated in our post-Realist world. It is a myth, however, which has persisted. This myth should continue to weave its way, because we, as a community, need to believe in it.

using my historical analysis to argue against Posner's call for an increased reliance on the social sciences. See Richard A. Posner, Against Constitutional Theory, 73 N.Y.U. L. REV. 1, 12 (1998). Given the history of the defense, it is not appropriate to apply law and economics in this setting. For a discussion of how law and economics might be applied in the context of the criminal law, see Christine Jolls et al., A Behavioral Approach to Law and Economics, 50 STAN. L. REV. 1471, 1538-47 (1998). 